\title{
Welfare, Child Care, and the People Who Care: Union Representation of Family Child Care Providers
}

\author{
Peggie R. Smith ${ }^{*}$
}

\section{INTRODUCTION}

Listen closely. You will hear a low but audible buzz within America's labor movement. At a time when the labor movement is sliding downhill, ${ }^{1}$ it may have found a useful foothold among a most unlikely group of women workers: family child care providers who, from within their private homes, care for children for compensation. ${ }^{2}$ Over the past few years, organized labor has reached out to these workers and, in the process, has confounded traditional thinking about unions and their responsiveness to the needs of women. Not very long ago, it seemed unimaginable that unions would cast their fortunes with family child care providers ("FCC providers"), and yet, in 2005, the Service Employees International Union (SEIU) organized more than 49,000 providers, netting organized labor in the United States its second largest victory since $1941 .^{3}$

This Article examines the legal struggle to organize and represent FCC providers who provide publicly subsidized care. ${ }^{4}$ The success and

\footnotetext{
Professor of Law, University of Iowa, College of Law; J.D., Harvard Law School, 1993; M.A., Yale University, 1990; B.A., Yale University, 1987. For helpful comments and suggestions during the writing of this Article, I wish to thank Katherine Baker, Stefanie Balandis, Rafael Gely, Martin Malin, Margaret Raymond, and participants at the Caring Labor Conference sponsored by the Harry Bridges Center for Labor Studies at the University of Washington. The research for this Article was supported by an appointment at the Obermann Center for Advanced Studies at the University of Iowa.

1. Thomas B. Edsall, Labor's Divisions Widen as Membership Declines, WASH. Post, Mar. 7, 2005, at A2; Steven Greenhouse, Splintered, But Unbowed, N.Y. TimeS, July 30, 2005, at C1; Robert B. Reich, Divided, They'll Stand-Maybe Even Taller, WASH. Post, July 31, 2005, at B4.

2. As ninety-eight percent of all child care workers, including family child care providers, are women, I refer to them as such throughout the Article. See infra Part III.A (reviewing the demographic composition of the child care labor force).

3. See infra Part VI.B (discussing the organization of FCC providers in Illinois).

4. As used in this Article, an FCC provider refers to an individual who provides child care services for compensation in her own residence to two or more unrelated children. See, e.g., KATIE Hamm \& Avis Jones-DeWeEver, Inst. For Women's Policy Research, FAmily Child Care: RECENT TRENDS AND NEW DIRECTIONS 1 (2004), available at http://www.kwdi.re.kr/data/wotrend2/ family_child_care_trends.pdf (defining an FCC provider "as a paid provider who cares for two or more unrelated children in her home, although the provider may care for her own children at the
} 
struggles of the SEIU are not without precedent. $^{5}$ The organization of family child care is part and parcel of labor's growing emphasis on lowwage service jobs. ${ }^{6}$ Organized FCC providers join the ranks of other low-wage service workers, including clerical staff, ${ }^{7}$ janitors, ${ }^{8}$ and home care workers, ${ }^{9}$ all of whom are contributing to labor's struggle to retain

same time"). FCC providers are not a monolithic group. Some providers are regulated while others are not, and a significant percentage of providers escape all government oversight by operating as part of an underground economy. See infra notes 62-67 and accompanying text (discussing distinctions among FCC providers). While the Article discusses issues that affect FCC providers as a group, the focus on unionization is limited to those providers who provide publicly subsidized care.

5. The American Federation of State, County and Municipal Employees (AFSCME) is also involved in organizing FCC providers. See, e.g., Dave DeWitte, AFSCME Claims Child-Care Win, GAZETTE (Cedar Rapids, Iowa), Feb. 7, 2006, at 1B (discussing the competition between SEIU and AFSCME to represent Iowa child care workers); Jennifer Jacobs, Unionizing Child Care Workers Applauded, Des MoINES Reg., Jan. 18, 2006, at 1B (same); Francine Knowles, Two Unions Clash Over Which One Will Represent Child-Care Workers, CHI. Sun-TIMES, Mar. 20, 2005, at 74 (discussing "turf battle" between SEIU and AFSCME for representation of Illinois child care workers).

In organizing FCC providers, SEIU and AFSCME have worked closely with community organizing groups such as ACORN (Association of Community Organizations for Reform Now) and DARE (Direct Action for Rights and Equality). See Maria D. Montilla et al., Models for Increasing Child Care Worker Compensation, in ChaRTING CIVIL Society, at 4 (Urban Inst., No. 8, June 2001), available at http://www.urban.org/UploadedPDF/cnp_8.pdf (discussing DARE's successful campaign to get the state of Rhode Island to extend health coverage insurance to child care workers); MARCY WHITEBOOK, CTR. FOR THE STUDY OF CHILD CARE EMPLOYMENT, WORKING FOR WORTHY Wages: The Child Care Compensation Movement, 1970-2001, at 46 (2002), available at http://www.iir.berkeley.edu/cscce/pdf/worthywages.pdf (discussing SEIU's coalition with ACORN to organize child care workers). Along with the focus on FCC providers, unions are also pushing to organize center-based child care workers. See Peggie R. Smith, Caring for Paid Caregivers: Linking Quality Child Care with Improved Working Conditions, 73 U. CIN. L. REV. 399, 426-28 (2004) (case study of center-based child care unionizing in Seattle).

6. See, e.g., Fernando Gapasin \& Michael Yates, Organizing the Unorganized: Will Promises Become Practices?, MONTHLY REV., July-Aug. 1997, at 46, 46-48, 51 (noting the decline of unions and opportunities to increase union density through organizing service workers); Pamela M. Prah, Labor Unions' Future, 15 CQ RESEARCHER 711, 713-17 (2005) (discussing the role unions play in the current economy and what the labor movement should focus on in the future); Symposium, Split to Win? Assessing the State of the Labor Movement, DissENT, Winter 2006, at 54, 54-60 (discussing the benefits to the labor movement of focusing on the service sector); Jeffrey M. Barker, Health Care Union Makes Major Push into Politics, Seattle Post-InTelligencer, Sept. 7, 2004, at B1 (observing that "SEIU has consistently looked to low-wage service sectors to increase its membership").

7. See Richard W. Hurd \& Adrienne McElwain, Organizing Clerical Workers: Determinants of Success, 41 INDUS. \& LAB. REL. REV. 360, 367-72 (1988) (analyzing the factors affecting the success of union organizing among clerical workers in the private sector).

8. See Richard W. Hurd \& William Rouse, Progressive Union Organizing: The SEIU Justice for Janitors Campaign, 21 Rev. RAdicAl POLITICAL ECON. 70, 73 (1989) ("[T]he Justice for Janitors campaign has experienced some success in increasing union membership and in consolidating wage gains and benefits."); Roger Waldinger et al., Helots No More: A Case Study of the Justice for Janitors Campaign in Los Angeles, in ORGANIZING TO WIN: NEW RESEARCH ON UNION STRATEGIES 102 (Kate Bronfenbrenner et al. eds., 1998) (analyzing "the recent growth of janitorial unionism in Los Angeles").

9. See Janet HeinRitZ-Canterbury, Paraprofessional Healthcare Inst., 
social currency, and who, in turn, have seen their own economic fortunes improve. Yet more so than any of these other groups, the mobilization of FCC providers demonstrates labor's willingness to rethink conventional union approaches in an effort to organize the unorganized. Viewed as babysitters by many, ${ }^{10}$ the women who comprise the family child care workforce sharply contrast with labor's historical focus on blue-collar, male factory workers. ${ }^{11}$

America's child care problem provides the backdrop for the organization of FCC providers. Far too many working parents, with too few dollars, lack access to affordable, quality child care. ${ }^{12}$ As welfare reform pushes former welfare recipients into the workforce, the problem has escalated. ${ }^{13}$ Not only are more parents in need of child care, but quality concerns have grown because unlicensed FCC providers deliver the bulk of publicly subsidized child care in many low-income communities. ${ }^{14}$ While this state of affairs has generated demands for

Collaborating to Improve In-Home SupPortive Services: Stakeholder Perspectives on IMPLEMENTING CALIFORNIA's PUBliC AUTHORITIES 4-6 (2002), available at http://www. paraprofessional.org/publications/CA\%20PA\%20Report.pdf (summarizing organization and progress of California's In-Home Supportive Services Program); Linda Delp \& Katie Quan, Homecare Worker Organizing in California: An Analysis of a Successful Strategy, 27 LAB. STUD. J. 1, 18 (2002) ("[T]he homecare organizing campaign . . . had economic and social significance far beyond organizing.").

Home care refers to services provided to disabled and elderly individuals that enable them to live independently in their own homes. Such services include housekeeping, cooking, shopping, and assistance with personal hygiene such as bathing. See infra note 117 and accompanying text (discussing home care).

10. See William T. Gormley, JR., Everybody's Children: Child Care as a Public PROBLEM 59 (1995) (observing that "many parents continue to think of providers as 'babysitters' despite vigorous efforts to purge that word from the child care vocabulary"); CAROLINE ZINSSER, Raised in East Urban: Child Care Changes in a Working Class Community 2 (1991) (referring to FCC providers as babysitters). See generally MARY TUOMINEN, WE ARE NOT BABYsitTers: FAMILY CHILD CARE PROVIDERS REDEFINE WORK AND CARE (2003) (arguing for a reconceptualization of the social and economic value of FCC providers' work).

11. Charles B. Craver, Why Labor Unions Must [and Can] Survive, 1 U. PA. J. LAB. \& EMP. L. 15, 25 (1998) (observing that the "labor movement historically has derived its organizational strength from white, male, blue-collar employees residing in northern states"); Molly S. McUsic \& Michael Selmi, Postmodern Unions: Identity Politics in the Workplace, 82 IowA L. REV. 1339, 1344 (1997) (commenting that the model worker targeted by unions reflected the image of white, married, male industrial workers); Dorian T. Warren \& Cathy J. Cohen, Organizing at the Intersection of Labor and Civil Rights: A Case Study of New Haven, 2 U. PA. J. LAB. \& EMP. L. 629, 632-33 (2000) (observing that the traditional model of organizing, which focused mainly on the concerns of white men, poses a challenge for organizing the disproportionate numbers of racial-ethnic groups and women in the service-sector workforce).

12. See Suzanne Helburn \& Barbara Bergmann, America's Child Care Problem: The WAY OUT 4-6 (2003) (discussing generally the "affordability problem" and the "quality problem").

13. See infra notes 29-49 and accompanying text (discussing the impact of welfare reform on the demand for child care).

14. TuOMINEN, supra note 10 , at 134 (noting, in reference to the family child care study that she conducted, "in lower-income communities and communities of color, state-subsidized children 
increased government regulation of family child care, ${ }^{15}$ it has also prompted providers to mobilize.

FCC providers clearly operated as self-employed members of a cottage industry in years past, ${ }^{16}$ but today they are more likely to view their work in the context of an employment relationship with the government if they care for children receiving publicly funded child care. In such instances, providers are subject to government regulations and are paid by the state $;{ }^{17}$ yet the compensation rarely affords providers decent wages. ${ }^{18}$ Indeed, government payments are so low that women who provide subsidized child care often qualify for such care for their own children. ${ }^{19}$ Remedying this situation has proven difficult, in part because collective bargaining statutes deny FCC providers the right to join forces in order to negotiate with government agencies over the terms of their labor arrangements. However, innovative unionizing approaches are beginning to alter this landscape.

The remainder of this Article is divided into five Parts. Together, Parts II and III pour the Article's foundation and build the necessary framework for the ensuing examination of labor's efforts to organize and represent FCC providers. Part II unpacks the significance of welfare reform to family child care and overviews government regulation of family child care. Part III examines the economic status of FCC providers and considers how government reimbursement rates, designed to compensate providers for the delivery of subsidized child care, serve to reinforce their economic vulnerability.

Parts IV, V, and VI turn to the unionization of FCC providers. All three Parts draw upon the SEIU's campaign to organize home care workers given the close structural and funding similarities between home care $^{20}$ and family child care. Part IV highlights the practical hurdles impeding the organization of FCC providers, such as worker

formed the majority of children served by the providers"); see also infra notes $51-57$ and accompanying text (discussing the poor quality in family child care).

15. See infra notes 59-67 and accompanying text (discussing various regulatory frameworks for family child care and overviewing government regulation of family child care).

16. See Sonya Michel, Children's InTERests/Mothers' Rights: The Shaping of AMERICA'S CHILD CARE POLICY 262-63 (1999) (suggesting an evolution of family child care over time from a point where FCC providers regarded themselves as babysitters and eschewed professionalism, to a point where some providers desired to become professionals and various groups began to emphasize the need for greater government regulation).

17. See infra notes 59-67 and accompanying text (overviewing government regulation of family child care).

18. See infra Part III.B (evaluating the process by which governments determine child care reimbursement rates)

19. TUOMINEN, supra note 10 , at 8,176 .

20. See infra notes $117-18,123-30$ and accompanying text (discussing home care). 
fragmentation and parents' limited financial resources. The question of whether providers are employees or independent contractors for purposes of collective bargaining statutes forms the heart of Part V. This Part analyzes case law addressing the question and discusses the limitations of the control test, as applied to FCC providers, to determine who is and is not an employee. Finally, Part VI explores an employer-of-record approach to organize and represent FCC providers. Premised on the state-action exemption to antitrust law, this approach provided the winning strategy that led to the organization of FCC providers in Illinois.

\section{FAMILY CHILD CARE: AN OVERVIEW}

The demand for child care has grown steadily as increasing numbers of women with children enter the workforce. ${ }^{21}$ Between 1947 and 2004, the labor force participation rate of mothers with children between six and seventeen years of age climbed from roughly twenty-five percent to more than seventy-seven percent. ${ }^{22}$ As a result of this upward trend, the provision of child care has changed dramatically. Whereas families once relied heavily upon "mother care" provided by stay-at-home moms, today more and more parents of young children are turning to a host of "other care" arrangements, including in-home care, relative care, family child care, group home care, and child care centers. ${ }^{23}$

It is difficult to calculate the number of child care workers in the United States and the settings in which they work because many workers are unregulated. The child care workforce is probably larger than the 1.3 million workers reported by the Department of Labor. ${ }^{24}$ Much of the underreporting occurs with respect to home-based child care because of

21. See Staff of the H. Comm. on Ways \& Means, 108Th Cong., 2004 Green Book 9-1 (Comm. Print 2004) [hereinafter GREEN BOOK], available at http://waysandmeans.house.gov/ media/pdf/greenbook2003/Section9.pdf (discussing child care and observing that the "dramatic increase in the labor force participation of mothers is the most important factor affecting the demand for child care").

22. Id. at 9-2; see also, Press Release, Bureau of Labor Statistics, U.S. Dep't of Labor, Status of the Population by Sex, Marital Status, and Presence and Age of Own Children Under 18, 2004-05 Employment Annual Averages (Apr. 27, 2006), http://www.bls.gov/news.release/famee.t05.htm (illustrating the 2004 "participation rate" for women "with own children 6 to 17 years, none younger").

23. See U.S. Gov't Accountability Office, GAO-04-786, Child Care: State EFforts to ENFORCE SAFETY AND HEALTH REQUIREMENTS 6 (2004) [hereinafter CHILD CARE: STATE EFFORTS] (describing "[t]ypes of child care eligible to receive funding under TANF and the block grant").

24. BUREAU OF LABOR STATISTICS, U.S. DEP'T OF LABOR, 2006-07 OCCUPATIONAL OUTLOOK HANDBOOK: CHILD CARE WORKERS 389, 391 (2005), available at http://www.bls.gov/oco/pdf/ ocos170.pdf. 
its location within the private setting. ${ }^{25}$ While precise numbers remain elusive, a recent study conducted by the Center for the Child Care Workforce, focusing on the care of very young children (ages zero to five), represents one of the more thorough attempts to fully capture the size and character of the workforce. ${ }^{26}$ The study estimates that 2.3 million workers care for very young children at any given moment and that family child care is the most popular form of nonparental, nonrelative care. ${ }^{27}$ Family child care has become so vital to working parents that, in many areas, it is the fastest growing segment of the child care industry. ${ }^{28}$

Arguably, the most critical force fueling family child care's growth is welfare reform legislation. In 1996, Congress passed the Personal Responsibility and Work Opportunity Reconciliation Act (PRWORA). ${ }^{29}$ The PRWORA eliminated the entitlement to federal child care assistance under Aid to Families with Dependent Children (AFDC) ${ }^{30}$ and replaced

25. See NAT'L Research CounCIL, Who CARES For AMERICA'S ChildRen? 151 (Cheryl D. Hayes et al. eds., 1990) (observing that "[s]ince many family day care providers operate in the underground economy ... precise estimates of their numbers and the number of children they serve are illusive").

26. See Ctr. For the Child Care Workforce \& Human Servis. Policy Ctr., Estimating THE SIZE AND COMPONENTS OF THE U.S. CHILD CARE WORKFORCE AND CAREGIVING POPULATION 3 (2002) [hereinafter EstimATING CHILD CARE WORKFORCE], available at http://www. ccw.cleverspin.com/pubs/workforceestimatereport.pdf (finding that "the economic and social contribution of child care workers and the projected future need for child care workers . . . have been seriously underestimated").

27. See id. at 2 (reporting that of the 2.3 million workers, twenty-four percent work in centerbased settings, "including private and public child care centers, Head Start programs, and prekindergarten programs"; twenty-eight percent are FCC providers; thirty-five percent "are paid relatives other than family child care providers"; and thirteen percent "are paid non-relatives other than those working in centers or family child care programs (e.g., nannies)").

28. See Amy R. Gillman, Surdna Foundation, Strengthening Family Child Care In LOW-INCOME COMMUNITIES 3 (2001), available at http://www.surdna.org/usr_doc/childcare.pdf (stating that "[f]amily child care is the fastest-growing segment of the child care industry and represents the most frequently used 'out of home' care in the country"); Tracie McMillan, Market Babies, CiTY Limits, Jan. 2003, at 20, 21 (observing that in New York City, "family child care has been the fastest-growing kind of regulated care the city pays for, increasing by roughly 38 percent between 1998 and 2002"); see also Jamaal Abdul-Alim, Rapid Growth of Day Cares Leaves Oversight Behind, MiLwAUKEE J. Sentinel, May 18, 2003, at 01A (observing in the context of Milwaukee County that "[t]he largest growth in the day care field has occurred in the number of state-licensed family child care centers"); Michele R. Marcucci, Bay Area Child Care in Short Supply, Expensive, OAKLAND TRIB., Feb. 7, 2002 (with respect to California, commenting that "most of the growth statewide is in smaller, family child-care homes, rather than larger centers"); Katherine Yung, A Lost Child, a Lost Livelihood; Child Care Tragedy Underscores High Stakes Regulators Face, Dallas Morning News, Feb. 3, 2002, at 1H (noting that family child care is "the fastest-growing form of child care in Texas").

29. Pub. L. No. 104-193, 110 Stat. 2105 (codified as amended in scattered sections of 8 and 42 U.S.C.).

30. See 42 U.S.C. $\S \S 601-17$ (1995), repealed by Temporary Assistance for Needy Families Act of 1996, Pub. L. No. 104-193, 110 Stat. 2105 (codified as amended at 42 U.S.C. $\S 601-19$ ) 
it with a block grant program known as Temporary Assistance for Needy Families (TANF). ${ }^{31}$ Unlike AFDC, which provided benefits to lowincome families as long as they had children under the age of eighteen ${ }^{32}$ and satisfied state-specified income levels, ${ }^{33}$ TANF limits benefit eligibility to a lifetime total of five years ${ }^{34}$ and imposes a work requirement on benefit recipients. ${ }^{35}$ According to the conservative estimate of one study, welfare reform prompted the movement of at least one million children into child care settings during the period from 1996 to $1998 .^{36}$ To help respond to the child care needs of welfare-to-work recipients entering the labor force, state and local governments throughout the country have promoted family child care. ${ }^{37}$

Family child care is an important child care option. Some parents prefer to place young children in family child care rather than in child care centers ${ }^{38}$ because of its family setting and location within individual

(2000) (stating that the purpose of the TANF "is to increase the flexibility of states in operating" child care programs).

31. 42 U.S.C. $\S \S 601-19(2000)$.

32. See 42 U.S.C. § 606(a) (1995), repealed by Pub. L. No. 104-193, 110 Stat. 2105 (defining "dependent child" as one who is under the age of eighteen).

33. 42 U.S.C. § 602(a)(7) (1995), repealed by Pub. L. No. 104-193, 110 Stat. 2105.

34. 42 U.S.C. $\S 608(a)(7)(2000)$.

35. 42 U.S.C. $\$ 602(a)(1)(A)($ ii) (2000).

36. See Bruce Fuller et al., Welfare Reform and Child Care Options for Low-Income Families, 12 FUTURE OF CHILDREN 97, 102 (2002) ("This estimate may be conservative, as it includes only families who were enrolled in work activities and those employed about a year after leaving welfare. Also, the estimate did not include the increasing number of older children who began spending time at home alone after school while their mothers were still at work."); see also MARIA L. HEIN ET AL., InST. FOR Soc. \& ECON. DeV., Home-BASEd Child CARE: Assessing the Self-Sufficiency POTENTIAL 1 (1999), available at http://www.ised.us/doc/Home\%20Based\%20Child\%20Care.pdf ("The demand for subsidized child care services is increasing as a result of welfare reform and its

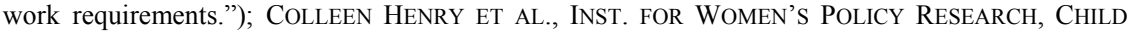
CARe Subsidies Promote Mothers' EMPloyment and Children's DeVelopment 3 (2003), available at http://www.iwpr.org/pdf/G714.pdf ("The need for child care assistance has been amplified by the 1996 welfare reform legislation's emphasis on increasing work participation for welfare recipients. The reforms have significantly increased the labor force participation of welfare receivers, resulting in a sharply expanded need for child care services.").

37. See Gillman, supra note 28 , at i ("With the advent of welfare reform, family child care has been touted by policymakers and others as a cost-effective way to quickly create employment opportunities and expand the child care supply in low-income communities.").

Policymakers have also encouraged welfare-to-work recipients to become child care workers, including FCC providers, notwithstanding the substandard working conditions that prevail in the field. See HeIN ET AL., supra note 36, at 1 ("A popular notion in many states is to encourage welfare recipients to become child care providers in order to meet the demand for child care and provide an avenue to self-sufficiency."); McMillan, supra note 28, at 21-23 (highlighting problems associated with turning welfare-to-work recipients into FCC providers); U.S. GEN. ACCOUNTING OFFICE, Welfare Reform: STATES' EFFORTS to EXPAND ChILD CARE PROGRAMS 20 (1998), available at http://www.gao.gov/archive/1998/he98027.pdf (observing that states "are funding efforts to support and encourage the entrance of new child care providers into the market").

38. U.S. GEN. ACCOUNTING OFFICE, WeLFARE REFORM: IMPLICATIONS OF INCREASED WORK 
homes. ${ }^{39}$ Relative to center-based care, parents often view family child care as nurturing and warm. ${ }^{40}$ Unlike the supposed rigidity associated with center care, the family atmosphere is thought to enhance opportunities for spontaneity. ${ }^{41}$ In addition, family child care offers the appeal of having one consistent caregiver whereas center-based care is often delivered by many different caregivers. ${ }^{42}$ Likewise, a family care setting frequently affords greater one-on-one attention as the adult-child ratio is generally lower than that in child care centers. ${ }^{43}$

For the majority of former welfare recipients, family child care also provides flexibility, convenience, and affordability when compared with center-based child care. Because low-income parents are disproportionately concentrated in jobs that demand night or weekend work, they require child care that will accommodate nontraditional work

PARTICIPATION FOR CHILD CARE 7 (1997) [hereinafter INCREASED WORK PARTICIPATION] ("Many mothers with children under the age of 2 who work full time place their children in the care of a family child care provider as opposed to a center or in-home setting. For example, in 1993, 40 percent of children under 1 year of age whose mothers worked were cared for in a provider's home; 38 percent of children between 1 and 2 were also cared for in this setting."); ELLEN GALINSKY, ET al., The Study of Children in Family Child Care and Relative Care: Highlights of FINDINGS 1 (1994) (commenting that "[c]are in the home of the provider is the most prevalent form of child care for young children with employed mothers in the United States today"); HAMM \& JONES-DEWEEVER, supra note 4, at 1 ("Infants and toddlers are more likely than older children to be placed in family child care homes.").

39. NAT'L RESEARCH COUNCIL, supra note 25, at 153 (“Among parents who prefer family day care, it is the intimacy of a small group and a home environment as well as a sense of shared values with the caregiver that are important." (citation omitted)). Some commentators suggest that much of the preference for family child care reflects an underlying emphasis on trust. See HAMm \& JonESDEWEEVER, supra note 4, at 1 (referencing research which "suggests that some mothers, particularly low-income and minority mothers, are more likely to trust relatives, friends or home-based providers who they can get to know on a more personal basis"); see also Fuller et al., supra note 36, at 104 (observing that welfare-to-work recipients often "trust kin members or friends more than centerbased caregivers because kith and kin offer familiar child-rearing practices and speak their language").

40. See Hamm \& Jones-DeWeEver, supra note 4, at 1 (commenting that the "idea of . . a a small, nurturing setting where siblings are grouped together is appealing to some parents" and that "some mothers may prefer a provider who shares similar cultural values or ideas about childrearing as opposed to a child care center where children may encounter multiple providers and policies that do not necessarily adhere to their own values"); MiCHEL, supra note 16, at 262 ("[F]amily caregivers tended to attract clients ... who expressed a preference for an environment that was 'warmer' and 'more homelike' than what was available at child care centers .....').

41. TUOMINEN, supra note 10 , at 60.

42. See id. at 62 (reporting observation of FCC provider who states that "'one part of [centerbased] child care I've never liked is the fact that people aren't concerned enough about who's handling that child and how often. Is it five or six people handling the child? Or is there just one main person who takes care of that child? I think children need that [one main person] because not only do they need to bond with their parents, they need a type of bonding with their caregiver."' (alterations in original)).

43. See id. (reporting the observation of one FCC provider: "Individual attention. Quiet time. Interaction with a limited number of people. Long-term relationships. These are all qualities that family child care providers value and see as essential to their provision of care."”). 
schedules. ${ }^{44}$ Compared with center-based care, family child care is more likely to afford parents the necessary flexibility to balance work obligations with parenting responsibilities. ${ }^{45}$ In addition, because there exists a dearth of center-based child care in poor communities, ${ }^{46}$ and because many low-income parents do not have ready access to transportation, ${ }^{47}$ family child care located in their neighborhoods

44. See, e.g., Ann M. Collins et Al., ABt. Assocs., InC., NAtional Study of Child Care FOR LOW-INCOME FAMILIES 89 (2000), available at http://www.abtassoc.com/reports/NSCCLIF.pdf ("The most frequently reported [child care] shortage was in care offered for non-traditional hours, i.e., evenings, nights, weekends, holidays, as well as care that accommodates variable and swing shifts. For families leaving welfare, and for other low-income families, this is often the kind of care that their work schedules require."); HAMM \& JONES-DEWEEVER, supra note 4, at 1 (observing that many "low-income women in the aftermath of welfare reform . . . have jobs requiring shift work"); Linda C. McClain, Care as a Public Value: Linking Responsibility, Resources, and Republicanism, 76 CHI.-KENT L. REV. 1673, 1694 (2001) (“The terms and conditions of many low-income jobs (e.g., unusual hours, nontraditional jobs) make the task of finding such childcare especially difficult, if not impossible."); Margy Waller, Welfare-to-Work and Child Care: A Survey of the Ten Big States, 1997 PROGRESSIVE POL'Y INST. 2, available at http://www.ppionline.org/documents/welfare_childcare .pdf ("Most child care providers are available only during traditional work hours, while poor working mothers in entry level positions often need odd-hours child care because their new jobs do not have 9-to-5 work day hours.").

45. See Hamm \& Jones-DeWeEver, supra note 4, at 1 (noting that "[w]hereas child care centers tend to operate only during traditional business hours, family child care providers are much more likely to provide care at other times"); Juliet Bromer \& Julia R. Henly, Child Care as Family Support: Caregiving Practices Across Child Care Providers, 26 CHILD. \& YouTH SERviCes Rev. 941, 947 (2004) (observing that relative to center-based child care programs, "[h]ome-based child care settings offer a greater range of hours and provide more flexibility to incorporate part-time, fulltime, and variable parental work schedules"); Melissa Wavelet \& Jacquie Anderson, Promoting SelfSufficiency: What We Know About Sustaining Employment and Increasing Income Among Welfare Recipients and the Working Poor, 22 Focus 56, 56 (2002) (noting that "those who leave cash assistance for work tend to have low retention rates, and employment is often intermittent, at nontraditional hours (evenings, weekends), and without a fixed schedule").

46. See Claire Huntington, Welfare Reform and Child Care: A Proposal for State Legislation, 6 CORNELL J.L. \& PUB. POL'Y 95, 113 (1996) (noting the shortage of center-based child care in lowincome neighborhoods); Diane Hirshberg, Child Care Demand \& Supply under CalWORKs: The Early Impacts of Welfare Reform for California's Children, 1998-2000, at 2 (Policy Analysis for Cal. Educ., Working Paper No. 02-3, 2002), available at http://pace.berkeley.edu/wp_02-3.pdf (observing that "[t]he distribution of licensed centers is not equitable across communities. A greater supply of center-based care is found both in affluent neighborhoods and in communities where the average educational attainment of parents is higher").

47. See Ann Collins \& Barbara Reisman, Child Care Under the Family Support Act: Guarantee, Quasi-Entitlement, or Paper Promise?, 11 YALE L. \& POL'Y REV. 203, 208 (1993) (noting that "difficulties such as not owning an automobile or lack of accessible public transportation can make traveling from the home to the child-care site and to the worksite very complicated"); Erin Holland, From Welfare to Work: What the 1996 Welfare Reform Initiative Has Meant for Children, 11 Geo. J. ON POVERTY L. \& POL'Y 115, 121 (2004) (observing that "low-income inner-city residents, who often do not own their own vehicles, face difficult employment choices"); Martin Wachs \& Brian D. Taylor, Can Transportation Strategies Help Meet the Welfare Challenge?, $64 \mathrm{~J}$. AM. PlanNing Ass'N. 15, 16 (1998) (observing "that dependence on public transit reduced employment access far more than did any other factor analyzed, including residential location"). See generally Demetra Smith Nightingale, Transportation Issues in Welfare Reform: Background Information, URBAN INST., Dec. 17, 1997, available at http://www.urban.org/publications/ 410369.html (describing the role of transportation in welfare reform). 
becomes critical. ${ }^{48}$ Finally, poor parents often opt for family child care because it is frequently less expensive than center-based care. ${ }^{49}$

The reliance on family child care by low-income parents raises two interrelated concerns: the quality of care and the economic status of FCC providers. As the following discussion highlights, the dismal quality of care has prompted calls for greater regulation of family child care and improved training of FCC providers. This desire is understandable given that poor child care quality negatively affects the well-being of children receiving such care. ${ }^{50}$ Yet the focus is unduly myopic, as it fails to consider the status of the workers and the strong nexus that exists between improved working conditions and improved quality of care.

Studies indicate that, on average, the quality of family child care is "mediocre." 51 For example, one study that evaluated FCC providers concluded that thirty-five percent offered inadequate care, while only nine percent provided good quality care, and fifty-six percent provided adequate care. ${ }^{52}$ These findings are not surprising since FCC providers, as a group, possess limited experience, training, and formal education in the child care field. ${ }^{53}$ While the correlation between these human capital variables and outcomes for children in child care has fostered some debate, ${ }^{54}$ ample evidence indicates that children fare better when child care workers possess adequate training and/or education. Specifically, research shows that providers with relevant training and education engage in more positive interactions with children, display higher levels

48. See Ill. Facilities Fund, We Need More Day CARe Centers 4 (2003), available at http://www.iff.org/resources/content/3/6/documents/iff_latino_study.pdf ("Some neighborhoods have no child care centers at all. In other communities, centers are difficult to reach by public transportation or have long waiting lists."); see also GILLMAN, supra note 28, at 4 (stating that "in many low-income neighborhoods family child care is the only type of child care available").

49. See HAMM \& JONES-DEWEEVER, supra note 4, at 1 ("New need for child care, especially among low-income families, has resulted in an increased reliance on family child care out of both maternal preference and monetary necessity.").

50. See infra notes 53-57 and accompanying text (discussing the correlation between poor child care quality and the well-being of the children in such care).

51. See Suzanne W. Helburn \& Carollee Howes, Child Care Cost and Quality, 6 FUTURE OF CHILD. 62, 68 (1996) (observing that overall family child care is "mediocre"); Suzanne W. Helburn et al., Family Child Care Finances and Their Effect on Quality and Incentives, 17 EARLY CHILDHOOD RES. Q. 512, 514 (2002) (noting that "[s]tudies of quality of services indicate mediocre to poor quality services in the majority of family child care homes").

52. Helburn \& Howes, supra note 51, at 68.

53. Id. at 69 .

54. See, e.g., HAMM \& JONES-DEWEEVER, supra note 4, at 2 (observing that "[m]easures of quality are not without controversy"); James Elicker et al., The Context of Infant Attachment in Family Child Care, 20 J. Applied Developmental Psychol. 319, 323 (1999) ("Existing evidence on the impact of child care provider experience is equivocal. Some studies have found years of experience to be linked to more positive caregiving, whereas others have not."). 
of sensitivity toward them, and are more aware of safety and health issues, relative to providers who lack such training and education. ${ }^{55}$ Research also reveals a link between job turnover among child care providers and child care quality. Children in stable child care situations "have more secure attachments, higher complexity of play, more advanced language development, and better school achievement." These positive outcomes, however, often fall by the wayside given that fifty-nine percent of FCC providers experience job turnover each year. ${ }^{57}$

Although poor quality plagues the child care field generally, ${ }^{58}$ the family child care problem is magnified because it often occurs informally and frequently escapes government oversight. No uniform regulatory framework applies to the child care industry, although all states impose some level of oversight to help protect children in child care settings. ${ }^{59}$ At a minimum, states require licensed providers to satisfy criminal background checks, pass a facilities inspection, submit to periodic compliance inspections, and meet training criteria. ${ }^{60}$ However, whereas most child care centers must satisfy licensing requirements, significant variations exist in family child care. ${ }^{6}$

FCC providers loosely fall into three groups, depending on the level of government oversight: licensed, certified, and nonregulated. Licensed

55. See Judith Bordin et al., The Relation of Quality Indicators to Provider Knowledge of Child Development in Family Child Care Homes, 29 CHILD \& Youth CARE F. 323, 336 (2000) (stating that "training . . . may be a powerful way to promote responsive and developmentally appropriate care"); Sara Gable \& Amy Halliburton, Barriers to Child Care Providers' Professional Development, 32 ChiLd \& Youth CARE F. 175, 175-76 (2003) (discussing the "positive relationship between child care provider educational preparation and the quality of children's experiences"); H. Abigail Raikes et al., Regulation, Subsidy Receipt and Provider Characteristics: What Predicts Quality in Child Care Homes?, 20 EARLY CHILDHOOD Res. Q. 164, 165 (2005) (stating that "child care quality ... is affected by provider characteristics, such as the amount of training and education the provider has received").

56. Christine M. Todd \& Deanna M. Deery-Schmitt, Factors Affecting Turnover Among Family Child Care Providers: A Longitudinal Study, 11 EARLy CHILDHOOD RES. Q. 351, 351-52 (1996).

57. Id. at 352 .

58. HELBURN \& BERGMANN, supra note 12, at 5-6.

59. Id. at 126.

60. Child CARe: State EFForTs, supra note 23, at 6.

61. See COLLINS ET AL., supra note 44, at 69 (noting that while regulatory requirements vary for center-based care, "[t]he greatest variation in regulation is for small family child care homes, which fall under the overall regulatory system in only some of the states"); TONI PORTER \& SHANNON M. KEARNS, SUPPORTING FAMILY, FRIEND AND NEIGHBOR CAREGIVERS: FINDINGS FROM A SURVEY OF STATE POLICIES 26 (2005), available at http://www.bankstreet.edu/gems/ICCC/ surveypaperfinal.pdf ("One of the most striking findings from our survey relates to the distinctions states create between home-based care that is subject to licensing and care that is exempt from these regulations. The variation is wide. Some states require anyone who cares for even one unrelated child to become a regulated family child care provider, while other states do not set a limit on the number of children in care if they are all from the same family."). 
FCC providers are typically subject to a level of oversight comparable to that which governs child care centers. As a threshold matter, they must satisfy criminal background checks, home inspections, and training requirements. ${ }^{62}$ The oversight of certified FCC providers, also referred to as registered FCC providers, ${ }^{63}$ is less rigorous than that which applies to licensed providers, ${ }^{64}$ and usually involves self-certification on the part of each individual provider that she meets basic health and safety regulations. $^{65}$ Finally, the third group, nonregulated FCC providers, consists of providers who, because they serve a small number of children, are not legally required to comply with health and safety regulations. ${ }^{66}$ Of course, in addition to these three groups, there exists a sizeable portion of FCC providers who, while legally subject to regulation, avoid the regulatory system and work as part of an underground economy. ${ }^{67}$

62. ChILd CARE: STATE EFFORTS, supra note 23, at 6.

63. Id. at 11 .

64. Id. at 7 .

65. Id.

66. In determining which FCC providers to exempt from regulations, states typically set a regulatory threshold "at which regulation begins according to the number of children served by different types of providers and exempt from regulation those providers falling below these thresholds." Id. at 11. For example, providers in Illinois who care for three or fewer children are exempt, while in Missouri, the exemption kicks in if the provider cares for four or fewer children. DAN LeSSER ET AL., SupPorting All Our ChILDREN: CONFERENCE REPORT ON LiCENSE-EXEMPT HOME CHILD CARE IN ILlinOIS 8 (2002), available at http:/www.nclej.org/contents/childcare/ SupportingAllChildren.pdf.

Care provided by a relative or family friend, known as "kith and kin care," is frequently lumped into this category. See Ann Collins \& Barbara Carlson, Child Care by Kith and Kin-Supporting Family, Friends, and Neighbors Caring for Children (Nat'l Ctr. for Children in Poverty, Children and Welfare Reform Issue Brief 5, 1998), available at http://www.nccp.org/media/cwr98e-text.pdf ("Kith and kin child care is frequently, but imprecisely, referred to as 'informal care,' a term used to identify several types of care situations for which licensing is not required - from family child care providers who take care of fewer children than the minimum required for state licensing or registration, to nannies or au pairs, to grandmothers, to teenage baby-sitters, to cooperative arrangements between parents.").

It should be noted that, pursuant to federal law, even providers who would otherwise escape state regulations must comply with minimal regulatory standards in order to care for children receiving subsidized care. See COLLINS ET AL., supra note 44, at 76 ("At a minimum, the federal $\mathrm{CCDF}$ law requires all otherwise unregulated providers who receive subsidies to sign a selfcertification that they will comply with minimum health and safety requirements."); PORTER \& KEARNS, supra note 61, at 7 (noting that "Federal CCDF regulations delineate some minimum standards that states must apply to all providers who care for subsidized children").

67. See HAMM \& JONES-DEWEEVER, supra note 4, at 1-2 (commenting that "[w] hile the exact number of unregulated family child care providers is unknown, it is estimated that unregulated providers outnumber regulated providers"); NAT'L RESEARCH COUNCIL, supra note 25, at 154 (suggesting reasons why providers may avoid regulation); ZINSSER, supra note 10, at 2 (observing that many FCC providers "operate outside the regulatory system-because they either are exempt from regulations or choose not to become regulated"). 


\section{The ECONOMIC StATUS OF FAMILy CHILD CARE PROVIDERS}

The patchwork regulatory framework that governs family child care, combined with the increased use of such care, has fostered proposals for heightened government oversight of FCC providers and increased public funding to promote their professional development. While these proposals, and resulting programs, will presumably improve the quality of care, their value to providers is less clear. Importantly, "providers have very little economic incentive to invest in training and quality improvement, ${ }^{, 68}$ given that those who do provide quality care realize only small monetary gains for their work. ${ }^{69}$ Even as federal, state, and local governments have become more involved in all forms of child care, such involvement rarely bodes well for child care workers. To convey this troubling dynamic, the next Subpart surveys the economic status of child care workers, with a special emphasis on FCC providers, and examines the treatment of providers in publicly funded child care subsidy programs.

\section{A. Caring for Pennies}

Similar to the child care workforce in general, the overwhelming majority — ninety-eight percent—of all FCC providers are women. ${ }^{70}$ As a group, they are disproportionately poor women. In fact, the child care industry has more workers whose earnings fall below the poverty line than any other industry, and more than fifty percent of all providers earn poverty-level incomes. ${ }^{71}$ While exact wages are difficult to compute for

68. Helburn et al., supra note 51, at 534; see also GORMLEY, supra note 10, at 59 (commenting that "training carries with it meager financial rewards"); HAMM \& JONES-DEWEEVER, supra note 4, at 3 ("There are very few financial incentives in the child care market for improving child care. In general, family child care providers do not see an increase in income when they improve the quality of care or attend training.").

69. See GORMLEY, supra note 10, at 59 (commenting that few financial incentives come from training); Paula England \& Nancy Folbre, Care, Inequality, and Policy, in CHILD CARE AND INEQUALITY: RETHINKING CAREWORK FOR CHILDREN AND YOUTH 133, 133, 136 (Francesca M. Cancian et al. eds., 2002) (finding that caregiving often results in a wage penalty for workers involved in care work).

70. TUOMINEN, supra note 10 , at 5 .

71. Id. at 9. The following sources provide a glimpse into the annual earnings received by FCC providers. CHILDCARE WORKGROUP, INSURE THE UNINSURED PROJECT, OPTIONS TO INCREASE HeAlth COVERAGE OF THE CHILD CARE WORKFORCE 2 (2002), available at http://www.itup.org/ Workgroups/ChildCare/ChildCarereportAug2002.pdf (reporting that " $37 \%$ of [uninsured] family home providers [in California] had incomes of $\$ 20,000$ or less" and that " $50 \%$ of uninsured family home providers had incomes in excess of $\$ 30,000$ annually"; also noting that net incomes of family day care providers were significantly less because of expenses such as "food, toys, play materials, facility wear and tear, insurance, regulatory compliance and reporting, and accounting/bookkeeping 
providers, the available evidence confirms that their hourly earnings are extremely low and substantially less than workers employed as pet sitters, fast-food servers, and gas-station attendants. ${ }^{72}$ Moreover, most FCC providers earn low wages despite toiling exceedingly long hours, working an average of sixty hours per week. ${ }^{73}$ Along with low wages and long hours, family child care is characterized by few job-related benefits. Rarely do FCC providers receive benefits such as health insurance, vacation time, or retirement plans. ${ }^{74}$

Child care work is heavily mediated, not only by gender and class, but also by race. Racial-ethnic women are far more likely than white women to work in child care. Although they represent only thirteen percent of all paid workers in the labor force, racial-ethnic women account for a third of all paid child care workers. ${ }^{75}$ Indeed, "the representation of women of color is more than 250 percent higher in the

assistance"); CTR. FOR the Child CARE Workforce, A Profile of the SAN Mateo County CHILD CARE WORKFORCE 11 (2002), available at http://www.thecouncil.net/pdf_files/ 2002ChildWorkforce.pdf (reporting that the annual net income for a typical FCC provider in San Mateo County, California - who "has been in operation for ten years, works 61 hours per week, and cares for seven children"-is only \$21,955); RESOURCES FOR CHILD CARING ET AL., MEASURING UP: THE QUALITY OF CHILD CARE IN MiNNESOTA 1, available at http://education.umn.edu/ceed/ publications/briefsandreports/measuringup/mu15page.pdf (reporting that " $[\mathrm{t}] \mathrm{he}$ majority of family child care providers [in Minnesota] earned a net income of less than \$10,000"); VT. CHILD CARE Servis. Div., Vermont Child Care Wages, Benefits And CRedentials 2 (2002), available at http://www.state.vt.us/srs/childcare/research/WagesBenefitsCred.pdf (noting that in Vermont, "[f]orty-two percent of family child care providers have a net income of less than $\$ 10,000$ per year from their work"); Mike Comerford \& Nushin Huq, Home Child-care Workers Vote Overwhelmingly to Unionize, CHI. DAILY HERALD, Apr. 27, 2005, at 1 (reporting a recent study by the Illinois Department of Human Resources which indicated that approximately fifty-eight percent of all FCC providers in the state earn an annual income of less than $\$ 11,000$ per year).

72. CTr. For the Child CARE Workforce, CuRrent Data on Child Care Salaries and BENEFITS IN THE UNITED STATES 4 (2002), available at http://ccw.cleverspin.com/pubs/ 2002Compendium.pdf; see also TUOMINEN, supra note 10, at 9 (observing that "[i]n 1998 service station attendants and food servers were among those workers making higher wages than child care providers . . . even though the work week of family child care providers is 30 percent longer than that of these other occupations").

73. Helburn et al., supra note 51, at 521; see also NANCY L. MARSHALL ET AL., MASSACHUSETTS FAMILY CHILD CARE TODAY: A REPORT OF THE FINDINGS FROM THE MASSACHUSETTS COST AND QUALITY STUDY 6 (2003), available at http://www.wcwonline.org/ earlycare/FamilyChildCare2004.pdf (observing that "[p]roviders spent an average of 52 hours a week directly caring for children, plus an additional 10 hours a week, on average, on tasks related to their family child care business (such as doing laundry, food shopping, and record-keeping)").

74. CTR. FOR THE CHILD CARE WORKFORCE, supra note 72, at 3; see also MARCY WHITEBOOK ET AL., Ctr. For the Child CARE Workforce, Worthy Work, Unlivable Wages: The NATIONAL Child CARE StAFFing Study, 1988-1997, at 20 (1998), available at http:// ccw.cleverspin.com/pubs/worthywork.pdf (observing that while there have been improvements in the provision of health benefits to child care workers, "coverage . . . remains woefully inadequate, particularly given teachers' daily exposure to illness").

75. TUOMINEN, supra note 10, at 6 . 
child care work force than it is in the work force at large."76 In addition, a race-gender hierarchy exists within the child care industry that relegates racial-ethnic women to the poorest paying child care jobs, such as family child care. ${ }^{77}$

\section{B. Devaluing Child Care: The Problem of Low Reimbursement Rates}

These days, the low earnings that prevail in family child care must be understood in the context of child care subsidy policies implemented to further welfare reform goals. Such policies have helped to perpetuate the low-wage child care market. In order for welfare reform to succeed, poor working parents must have access to affordable child care. As part of its goal to bolster the provision of child care, Congress consolidated key sources of federal funding for child care subsidies into one block grant, the Child Care and Development Fund (CCDF). ${ }^{78}$ The CCDF provides federal funds to the states to develop child care programs targeted toward low-income working families. ${ }^{79}$ Under the CCDF, states must provide eligible families a choice among differing child care options, ${ }^{80}$ such as center-based care, group home care, family child care, and in-home care. ${ }^{81}$

76. Id.

77. Id. at 10; see also England \& Folbre, supra note 69, at 133 (observing that "[c]aregivers are disproportionately female. Further, women of color are overrepresented in many of the most poorly paid caring jobs, such as child care, elder care, and health care performed within clients' homes").

78. 45 C.F.R. $\S 98.1(b)(1)(2005)$

79. U.S. Gen. Accounting Office, Child Care: States Increased Spending on LowINCOME FAMILIES 7 (2001), available at http://www.gao.gov/new.items/d01293.pdf; Sandra L. Hofferth, Child Care, Maternal Employment, and Public Policy, 563 AnNALS AM. ACAD. POL. \& SOC. SCI. 20, 28 (1999)

80. 45 C.F.R. $\$ 98.30(\mathrm{e})(1)$ (2005); see also COLLINS ET AL., supra note 44, at 75 (stating that "[o]ne of the major principles of the Child Care and Development Fund is to provide families that receive subsidies a choice of all legally-available forms of child care").

81. The CCDF also provides that parents must be given the option of using kith and kin care. See supra note 66 (describing kith and kin care, and noting that even as such care would otherwise escape state regulations, if kith and kin providers care for children receiving subsidized care, they must comply with minimal regulatory standards pursuant to federal law).

For a description of the various child care categories, see ChILD CARE: STATE EFFORTS, supra note 23 , at 6 , which provides the following definitions of care providers: child care centers are "[n]onresidential facilities that provide care for children and include full- and part-time group programs, such as nursery and preschool programs. Child care centers can be commercial, work-site based, school-based (preschool or after school), or a recreational program (such as camps or parks), and care can also be run by a religious organizations [sic] or by federal, state, or local governments"; group home care means "[t]wo or more providers who provide child care services in a private residence other than the child's home (this does not include 24-hour residential facilities)"; in-home care is "[c]are provided in the child's home"; family child care refers to "[a]n individual provider who provides child care services as the sole caregiver in a private residence other than the child's home." 
States generally make subsidized funding for child care available to individual families in the form of a child care voucher or certificate which families can use to purchase care from among the available child care options. States reimburse providers based on the voucher or certificate once the providers submit an invoice. ${ }^{82}$ Reimbursement rates vary according to the type of provider and are generally set by the government without provider input. ${ }^{83}$ As a result of this process, FCC providers are usually compensated at rates that do not provide decent wages.

States establish provider reimbursement rates relative to the "market rate" for child care within a geographical area. ${ }^{84}$ This approach raises various red flags, including a concern that the market rate reflects harmful gender-based assumptions about the value of work performed primarily by women. Although labor market dynamics are portrayed as a fair basis for establishing wages, ${ }^{85}$ various commentators argue that discrimination against women has tainted the market's wage-setting process. $^{86}$ This argument has particular relevance to child care because

82. Rachel Schumacher et al., Ctr. For Law \& Soc. Policy, Untapped Potential? How States Contract Directly With Providers to Shore Up Child Care Choices For LOW-INCOME FAMILIES 41 (2003), available at http://www.buildinitiative.org/docs/untapped_ rpt.pdf.

83. U.S. Ass'N FOR Child CARE, CONDUCTING MARKET RATE SuRVEYS: How Does Your STATE RATE? 12 (2000), available at http://www.usachildcare.org/programs/kidsrate/ market_rate_report.pdf. As an alternative to vouchers, some child care centers provide child care through contracts. In the world of child care subsidies, contracts refer to "legal agreement[s] made between a state and a child care provider prior to service delivery that the provider will make available a certain number of child care slots, which will be paid for by the state so long as contracted state program or attendance conditions are met." SCHUMACHER ET AL., supra note 82, at 7. Importantly, "[c] ontract providers may negotiate for rates." Id. at 63.

84. See 45 C.F.R. $§ 98.43$ (b)(2) (2005) (requiring states to conduct market rate surveys and to use survey results to determine adequate payment rates); HEIN ET AL., supra note 36, at 4 (discussing how states set reimbursement rates).

85. See Richard A. Posner, An Economic Analysis of Sex Discrimination Laws, 56 U. CHI. L. REV. 1311, 1330-31 (1989) (outlining three qualifications for a competitive labor market to achieve comparable worth); see also Paul Weiler, The Wages of Sex: The Uses and Limits of Comparable Worth, 99 HARV. L. REV. 1728, 1757-59 (1986) (describing how the intrinsic value and ranking of jobs "could serve as the standard for fixing a fair rate of compensation for work traditionally performed by women").

86. See Ruth Gerber Blumrosen, Remedies for Wage Discrimination, 20 U. MICH. J.L. REFORM 99, 151 (1986) (noting that '[b]ecause the market rate for women's and minorities' jobs is likely to incorporate discriminatory wage-setting practices of all the employers who make up that market, employers should not be able simply to rely on 'the market"'); see also Nancy Gertner, Thoughts on Comparable Worth Litigation and Organizational Strategies, 20 U. MICH. J.L. REFORM 163, 166 (1986) (discussing how an allegedly neutral market devalues women's work and reflects discrimination); Deborah L. Rhode, Occupational Inequality, 1988 DUKE L.J. 1207, 1217-20 (1988) (observing that "[i]n theory, a well-functioning free market should serve to erode . . . discriminatory patterns," but "[e]ven reasonably competitive markets will permit . . . discrimination premised on generalizations that are inaccurate in a large percentage of cases, but are cheaper to indulge than to 
of the work's close association with women's unpaid work in the home. Even though paid child care is compensated labor, it suffers from a perception that caring for children, while socially important, is unskilled, emotional work of only marginal economic value. ${ }^{87}$ Family child care exacerbates this perception because, similar to domestic labor in the home, "it remains located within families, a site that historically promotes the invisibility of women and their care work." $" 88$ Research confirms that gender stereotypes have contaminated the market for child care such that child care workers experience a wage penalty. ${ }^{89}$

Use of the market rate as a reference point to establish provider reimbursement rates is also problematic because, in many low-income communities, the "government is often the primary or sole purchaser" of child care. ${ }^{90}$ Government agencies typically cap their rates at "a predetermined ceiling" that does not reflect the actual costs of child care. $^{91}$ Because of limited market competition in communities that rely heavily on subsidized child care, the market rate for child care becomes artificially low and is noticeably lower than rates charged by providers who do not care for subsidized children. ${ }^{92}$

PRWORA's failure to require states to set reimbursement rates at a minimum level relative to market rates further compounds this difficulty. Under AFDC, states had to set provider payment rates at the seventyfifth percentile of market rates. ${ }^{93}$ The seventy-fifth percentile rate is the rate at or below which at least seventy-five percent of providers in a category charge their clients. $^{94}$ The AFDC requirement assured

ignore").

87. See, e.g., TUOMINEN, supra note 10, at 42-46 (discussing the rationale behind the devaluation of child care); Paula England et al., Wages of Virtue: The Relative Pay of Care Work, 49 SOC. PROBS. 455, 457 (2002) (discussing the pay penalty of care work and its association with women and mothering); Deborah Rutman, Child Care as Women's Work: Workers' Experiences of Powerfulness and Powerlessness, 10 GENDER \& SOC'Y 629, 630 (1996) (discussing how child care has been perceived as emotional work of little value).

88. TUOMINEN, supra note 10, at 23.

89. See England et al., supra note 87, at 464 (finding that "working in a caring occupation leads to a significant net wage penalty ... for both men and women"); see also TUOMINEN, supra note 10 , at 46 (stating that "studies demonstrate that jobs requiring greater nurturance and caring skills are penalized when it comes to wages"); England \& Folbre, supra note 69, at 137 (discussing studies showing the net effect on pay of working in a job involving caring labor compared to other kinds of work).

90. U.S. ASS'N FOR CHILD CARE, supra note 83, at 5.

91. Id.; see also COLLINS ET AL., supra note 44, at 82 (noting that an additional concern with market rates for child care is that "the price of care [is] lower than the true cost of quality care and, by surveying price, rather than cost, the state . . . undermin[es] "quality"').

92. U.S. ASS'N FOR CHILD CARE, supra note 83 , at 5.

93. 45 C.F.R. § 255.4(a)(2)(iii) (1995), removed by 62 Fed. Reg. 64,301, 64,303 (Dec. 5, 1997); HEIN ET AL., supra note 36, at 4 n.4.

94. U.S. ASS'N FOR CHILD CARE, supra note 83, at 4 (citation omitted). 
providers that they would be reimbursed at a rate that was at least equivalent to the rate charged by seventy-five percent of providers in the market. However, while PRWORA encourages states to set their reimbursement rates at least equal to the seventy-fifth percentile of market rates, states are not obligated to do so. ${ }^{95}$ While some states do reimburse providers at or above this level, many do not. ${ }^{96}$

Low reimbursement rates hold troubling implications for all child care providers and pose particular challenges to FCC providers and the communities that they serve. States generally pay lower rates to FCC providers than they pay to centers that provide similar care. For example, in some cities in Oregon, FCC providers receive $\$ 2.39$ per hour to care for infants, while child care centers receive $\$ 3.29$ per hour to provide the same care. ${ }^{97}$ Likewise, in Illinois, FCC providers receive $\$ 21.53$ per day for children under two-and-a-half years of age, while child care centers receive $\$ 33.77$ per day for children under the age of two-and-a-half. ${ }^{98}$ As researcher Mary Tuominen comments, "[o]n the public-private continuum, women's care work that is most removed from the public sphere seems to have the least public value and receives the least economic reward." 99

State reimbursement systems also perpetuate existing class- and race-based disparities among FCC providers. Because racial-ethnic providers are more likely to care for subsidized children than white

95. See Child Care and Development Fund, 63 Fed. Reg. 39,936, 39,959 (July 24, 1998) ("In establishing payment rates we suggest a benchmark for States to consider. Payments established at least at the 75th percentile of the market would be regarded as providing equal access."); see also HEIN ET AL., supra note 36, at 4 (noting that "[a]lthough current federal child care regulations require states to complete market rate surveys every two years, the regulations do not set a minimum level for provider payment rates").

96. See, e.g., Child Care Helps Families Work and Children Learn: Hearing on Child Care and Development Block Grant Before the Subcomm. on 21st Century Competitiveness of the H. Comm. on Education and the Workforce, 107th Cong. (2002) (statement of Helen Blank, Director of Child Care and Development, Children's Defense Fund) (stating that "[n]early half of the states . . . set their [provider reimbursement] rates below the 75th percentile of the market rate- the rate that gives families access to 75 percent of their community's providers — or base them on outdated market rate surveys"); HEIN ET AL., supra note 36, at 4 (reporting that "only 18 states paid providers at or above the 75th percentile"); U.S. ASS'N FOR CHILD CARE, supra note 83, at 4 (observing that "[s]ome states pay above the 75th percentile while others reimburse providers at rates well below the 75th percentile"); Susan Traub, Note, Child Care \& PRWORA: Paying the Babysitter or Investing in Early Education?, 9 GEO. J. ON POVERTY L. \& POL'Y 249, 262 n.89 (2002) (commenting that "only three states, Florida, Maine, and Oklahoma, pay above market rates in certain circumstances").

97. OR. DeP'T OF Human SeRvs., Child CARE SubSIDY RATES, http://www.oregon.gov/DHS/ children/childcare/ccrate1.shtml (last visited Sept. 22, 2006).

98. State of Ill. DeP’T of Human Servs., Child Care Payment Rates (2000), available at http://www.dhs.state.il.us/chp/ofh/MIH/pdf/rates2000cc.pdf.

99. TUOMINEN, supra note 10 , at 177 . 
providers, ${ }^{100}$ a greater percentage of their earnings comes from the government. Few providers who live in middle- or upper-class communities will accept children receiving state subsidies because they can earn more money than the state will pay them. ${ }^{101}$ By contrast, providers in low-income communities, constrained by their own economic circumstances as well as those of their potential clientele, cannot afford to refuse to provide state-subsidized care. ${ }^{102}$ Because the government ties reimbursement rates to specific geographical areas, it pays less for child care in low-income communities relative to the rates charged by providers in more affluent neighborhoods ${ }^{103}$ and, in the process, reinforces racial-ethnic and class inequalities between communities. ${ }^{104}$

It is against the foregoing backdrop that one must appreciate the struggle of FCC providers to secure collective bargaining rights and resist exploitation at the hands of state government agencies responsible for administering child care subsidy programs. ${ }^{105}$ Although some commentators question the wisdom of unionizing child care, ${ }^{106}$ "unions

\footnotetext{
100. Id. at 134 .

101. See id. at 136-40 (providing real life examples of such providers).

102. See id. at 141-47 (providing real life examples of such providers).

103. Id. at 137.
}

104. Id. at 129. The treatment of FCC providers who deliver subsidized care epitomizes the government's abdication of its responsibility and its willingness to exploit workers who already exist on the economic margins of society. Having committed to welfare reform and having recognized that child care is critical to effectuate welfare reform's goals, states have effectively passed a considerable portion of the costs of reform on to FCC providers in the form of substandard compensation. Moreover, states have arguably turned to family child care in part because of the job's poor wages. Absent adequate public funding for child care, states have seized upon family child care as a low-cost approach to help provide child care to welfare-to-work recipients. Arguably, state policymakers view family child care as a potential solution to the problem of insufficient child care in poor communities precisely because women in those communities have long provided such care for little pay and no benefits.

105. As noted earlier, unions have targeted those FCC providers who care for children receiving publicly funded child care. Consequently, unionization is not a viable option for the many FCC providers who operate as part of an underground market and who look to avoid regulation at all costs. It is also safe to assume that such providers would have little, if any, interest in unionization. See, e.g., GORMLEY, supra note 10, at 60 (observing that "many providers view government regulation with skepticism, fear, or outright hostility"); NAT'L RESEARCH COUNCIL, supra note 25, at 154 (listing reasons providers remain unregulated). Even among providers who do deliver publicly subsidized child care, attitudes towards unionization may be mixed. For example, providers who have very little commitment to the job and view themselves as only temporary workers will likely have limited interest in unionization. See, e.g., Michel, supra note 16, at 262 (observing that some FCC providers see themselves as temporary workers). In addition, providers may be opposed to unionization to the extent that it represents greater oversight or involvement from the government.

106. See NAT'L RESEARCH COUNCIL, supra note 25, at 182 (observing that "many early childhood experts express concerns about the effects of unions on the nature of the intimate relationships between staff, parents, and children in child care"); see also JIM MORIN, TAKING Matters into Our Own HANDS: A Guide to Unionizing IN THE Child CARE Field 15 (1991) 
can play an instrumental role both in alleviating the vulnerability of workers and in linking child care quality with improved working conditions." ${ }^{\prime 107}$ Importantly, unions have demonstrated an ability and a willingness to pursue a comprehensive approach to the problem of inadequate child care funding, an approach that recognizes that the problem is not only a matter of child care affordability and availability for consumers, but also a labor issue for child care workers. ${ }^{108}$

\section{PRACTICAL CHALlENGES TO ORGANIZING AND REPRESENTING FAMILY CHILD CARE PROVIDERS}

While unions can assist FCC providers in negotiating with the state to gain improved working conditions and higher wages, organizing this group of workers presents numerous practical and legal obstacles. This Part considers the practical challenges of organizing and bargaining for FCC providers. Parts V and VI then explore in depth the primary legal hurdle that must be addressed: the exclusion of FCC providers from collective bargaining statutes.

As with many low-wage service jobs, family child care clashes with the model of work site unionism that undergirds the collective bargaining process in this country. Developed and perfected against the landscape of manufacturing jobs, work site unionism functions best when applied to a group of workers who labor for a common employer and at a common workplace that has a fixed location. In such an environment, labor organizers can easily identify both the employer as well as the potential bargaining unit. As I observed in the context of private-paid household workers, this type of identification is extremely difficult in occupations where workers are both hidden inside the private sphere of the home and work in isolation from each other without a common workplace. ${ }^{109}$ The one-on-one character of the family child care relationship - where an individual provider interacts with several parents, but does so separately with each one-stands in sharp opposition to the vision of collective bargaining.

The personal quality of family child care further complicates the organization of FCC providers. Contrary to the typical manufacturing

\footnotetext{
(noting that a challenge to organizing is that "[c]hild care teachers often do not perceive themselves as the 'type' who join unions").

107. Smith, supra note 5, at 421 .

108. Id. at 431

109. Peggie R. Smith, Organizing the Unorganizable: Private Paid Household Workers and Approaches to Employee Representation, 79 N.C. L. REV. 45, 70-71 (2000).
} 
job, many service jobs, family child care included, involve personal service "with workers interacting directly with clients, patients, or customers. The presence of these third parties complicates the conventional 'us-them' view of workplace relations." care, providers often develop strong emotional and personal bonds with the children for whom they care. When providers describe what they most enjoy about their work, they commonly reference the emotional connections that they have with their young charges and frequently describe their work as an act of "mothering." "111 This type of emotional attachment does not mesh readily with a model of unionism that embraces confrontation and opposition. ${ }^{12}$

Strategies for union representation of the child care workforce must also allow for the fact that many families are simply unable to pay child care workers decent wages. In light of this reality, child care unionization may have difficulty garnering public support if the bargaining process undermines parents' ability to afford child care or sacrifices the interests of children receiving such care. This observation is especially relevant to family child care because it caters disproportionately to the working poor. Thus, contrary to most successful union negotiations, where consumers typically shoulder the costs of improved labor conditions in the form of higher prices, it is unreasonable to expect parents, as child care consumers, to bear the costs associated with enhanced wages or benefits for FCC providers. If labor is to help FCC providers secure improved wages and working conditions, it must push for increased public support and funding for child care. ${ }^{113}$

110. Id. at 69 .

111. TuOminen, supra note 10, at 50-51; Julia Wrigley, Other PeOple's Children: AN Intimate ACCount of the Dilemmas Facing Middle-Class Parents and the Women They HIRE TO RAISE THEIR CHILDREN 86 (1995).

112. On this point, it is worth noting that anecdotal evidence suggests that segments of the child care workforce may be reluctant to participate in highly confrontational tactics. See, e.g., DAN Bellm, New ApProaches to ORganizing IN the ChILD CARE INDUSTRY 3 (2003), available at http://www.laborproject.org/publications/pdf/bellm.pdf ("Wariness and anti-union sentiments are common within this workforce, although there are signs of growing openness. Typical concerns include: Will unions go against my concern for the children and my relationships with families?").

113. See WhiteBOOK, supra note 5, at 16 ("“To meet the needs of child care staff for a decent income and of parents for affordable services, either government or industry will have to bear its share of the cost. Obtaining increased financial support will require changing the prevailing view that child care is unskilled work and enhancing public appreciation of it." (quoting Marcy Whitebook et al., Who's Minding the Child Care Workers? A Look at Staff Burn-out, CHILDREN TODAY, Jan.-Feb. 1981, at 2, 2-6)); see also ANNE L. ALSTOTT, No EXIT 66-68 (2004) (discussing the public goods argument for child care); NANCY FOLBRE, THE INVISIBLE HEART 5-6 (2001) (outlining arguments for treating child care as a public good); HELBURN \& BERGMANN, supra note 12 , at 5-6 (same). 
Although formidable, these obstacles are not insurmountable. To respond effectively to them, labor must rethink conventional models of organizing and develop alternative approaches that can respond to the specific challenges of home-based, low-wage care work. Labor has achieved gains on this front that can prove useful to organizing FCC providers. The successful unionization of home care workers is particularly instructive.

Home care workers enable elderly and disabled individuals to live independently by helping them perform a range of household activities such as cleaning, meal preparation, and assisting with personal hygiene tasks. $^{114}$ In the 1980s, the labor movement initiated a campaign to organize the California home care workforce. ${ }^{115}$ The campaign, which spanned twelve years, confronted many of the aforementioned challenges that face FCC providers, in particular, worker fragmentation, potential divisiveness between consumers and workers, and limited consumer resources. ${ }^{116}$

Similar to family child care, home care work occurs within the private sphere of the home, although the homes at issue belong to the care recipients and not to the workers. ${ }^{117}$ Lacking a common work site, the home care workforce is highly fragmented, and workers rarely have occasion to come together as a group. ${ }^{118}$ Consequently, union organizers turned to a labor-intensive, door-to-door grassroots organizing approach in order to find and mobilize the workers. ${ }^{119}$ Organizers " went to senior citizens' centers, doctor's offices, markets, churches . . . [and] even dug in trash cans to find lists of workers." ${ }^{120}$ A comparable grassroots

114. Delp \& Quan, supra note 9, at 3.

115. See Stu Schneider, Victories for Home Health Care Workers, Dollars \& SENSE, Sept.Oct. 2003, at 25, 25 (noting that the SEIU first attempted to organize California-based home care workers, who worked for the state, in the 1980s); see also Immanuel Ness, Organizing Home Health-Care Workers: A New York City Case Study, 3 WoRKINGUSA 59, 71-80 (1999) (discussing the campaign to organize home care workers in New York).

116. See Ness, supra note 115 , at 82 (detailing the importance of mobilizing an atomized work force, clients, and state and municipal governments).

117. Another relevant similarity between home and family child care is the composition of the workforce. Like FCC providers, home care workers are overwhelmingly female and disproportionately women of color. See Delp \& Quan, supra note 9, at 3 (stating that home care workers are primarily women and persons of color); Ness, supra note 115, at 69 ("[T] he industry predominantly consists of middle-aged minority women. ...").

118. Delp \& Quan, supra note 9, at 4; see also HeINRITZ-CANTERBURY, supra note 9, at 11 ("Recruiting union members in home care differs from most other industries, because home care provides no common work site - no shop floor where employees work together.").

119. See Delp \& Quan, supra note 9, at 6-8 (detailing the activities of the union's grassroots organizing approach).

120. Id. at 6 (quoting interview by Linda Delp with Verdia Daniels, President, SEIU Local 434B, in L.A., Cal. (May 6, 2000)); see also HEINRITZ-CANTERBURY, supra note 9, at 19 n.8 (noting 
strategy holds promise for reaching out to FCC providers, particularly those providers who, while providing subsidized care, are unlicensed. Unions should have an easier task locating licensed FCC providers, as states routinely keep public referral lists of such providers. ${ }^{121}$ Also, in some areas, providers may gather together as members of state and local FCC provider networks or associations. ${ }^{122}$

As with family child care, the majority of home care consumers lack the financial resources to improve the wages of home care workers. ${ }^{123}$ As one commentator observed, home care "[u]nionization meant the possibility of wage demands and strikes against elderly and disabled consumers. If the workers became pitted against the consumers, the public might well sympathize with the consumers."124 To minimize the likelihood of this outcome, labor formed a strong coalition that represented a partnership, first and foremost, between workers and consumers, but which also attracted the backing of community organizations and advocacy groups. ${ }^{125}$ The coalition's success required that the group demonstrate to consumers that they shared common interests with workers and convince them that unionization was not a “"zero sum' proposition in which increased wages for workers could only come at the expense of fewer hours of care for consumers." 126 Working as part of a coalition, labor effectively made the case that the problems that had long plagued home care services, including high turnover rates and poorly trained workers, could be ameliorated by transforming home care work into a decent job. ${ }^{127}$ The coalition recognized the financial constraints on consumers and made it a priority to mobilize public

that organizers contacted home care workers through "house visits, mailings, and other outreach"); Ness, supra note 115, at 73 (highlighting tactics to overcome worker "atomization" including "public hearings, rank-and-file lobbying, polling, coalition building, rallies, organized press campaigns, and soliciting support from prominent leaders and public officials").

121. See InCREASED WORK PARTiCiPATION, supra note 38, at 6 ("States and localities maintain data about providers that can help parents in choosing a provider ....").

122. See, e.g., WhiteBook, supra note 5, at 30-31 (discussing Direct Action for Rights of Equality, a grassroots family child care association in Rhode Island); Fred Brooks, New Turf for Organizing: Family Child Care Providers, 29 LAB. STUD. J. 45, 50 (2005) (suggesting that it may be easier to recruit FCC providers than home care workers because many "providers are members of informal networks and are well connected to other providers through these associations"); McMillan, supra note 28, at 23-24 (discussing family child care networks in New York City).

123. See Delp \& Quan, supra note 9, at 4-5 (noting that many consumers of home care do not have the ability to increase the wages of workers like normal employers do).

124. Id. at 5 .

125. Id. at 11-12; see also Ness, supra note 115, at 64 (noting the importance of "political coalitions" and "movements" in gaining political power for workers).

126. Delp \& Quan, supra note 9, at 12.

127. HEINRITZ-CANTERBURY, supra note 9, at 20. 
support to pressure state and local governments to provide greater funding for home care services. ${ }^{128}$

As I wrote elsewhere, ${ }^{129}$ this approach suggests three key lessons for the organization of family child care.

First, in order to improve the wages of child care workers, unions must affirmatively push for enhanced public support of child care. Second, such a push needs to emphasize the critical connection between quality care and decent working conditions. Third, unions need to unite a broad base coalition around the issue of child care that will clearly convey that child care is a matter of public concern. To this end, unions should look to forge partnerships with interested constituencies including parents, child care employers, as well as community groups.

Although resolution of the practical challenges facing family child care's organization is a critical step, labor must also figure out how to represent FCC providers even as popular opinion views them as self-employed, independent contractors.

\section{INDEPENDENT CONTRACTORS OR PUBLIC EMPLOYEES?}

Federal antitrust law presents a significant barrier to the representation of FCC providers. The Sherman Act prohibits "[e]very contract, combination ... or conspiracy" that unreasonably restrains competition. ${ }^{131}$ While labor organizations are exempted from antitrust law, ${ }^{132}$ the exemption extends only to the organization of employees, not

128. See Delp \& Quan, supra note 9, at 11-14 (explaining that consumers already had established lobbying groups).

129. Peggie R. Smith, Laboring for Child Care: A Consideration of New Approaches to Represent Low-Income Service Workers, 8 U. PA. J. LAB. \& EMP. L. 583 (2006).

130. Id. at 621; see also WHITEBOOK, supra note 5, at 14 (commenting on the early efforts of child care activists and noting that while "[t]raditional workplace organizing was viewed as an important tool for improving child care jobs, . . . it was also necessary to pursue a public policy strategy to leverage additional public resources beyond parent fees to create the necessary funding base for change" and that "[f]rom the onset, [the child care] movement was about more than improving the lot of child care workers. They connected the well-being of children and families with their own well-being. Teacher advocates were explicit about the link between the quality of child care jobs and the quality of services. They wanted more respect and better pay for themselves, but they were just as deeply committed to upgrading the care and education"); Brooks, supra note 122, at 58-59 (noting the importance of linking public issues with union issues in family child care).

131. 15 U.S.C. $\S \S 1-7$ (2000).

132. Section 6 of the Clayton Act immunizes labor organization activities designed to carry out the "legitimate" purposes of labor unions from liability under antitrust laws. Clayton Act, ch. 323, § 6, 38 Stat. 730, 731 (1914) (current version at 15 U.S.C. $\S 17$ (2000)). Section 6 of the Clayton Act provides: "The labor of a human being is not a commodity or article of commerce. Nothing 
independent contractors. ${ }^{133}$ Working out of their homes and arranging with individual parents to provide child care, FCC providers appear to fall squarely under the heading of independent contractors. Yet some providers assert that they are state employees, and as such should possess labor rights, including the right to organize and engage in collective bargaining. This assertion underscores the pervasiveness of child care regulations in some states as well as the extent to which states, through the use of child care subsidies, pay for the services of FCC providers. While many providers remain outside the scope of regulation or are subject to only minimal oversight, others find that they must comply with such a host of regulations that the question arises as to whether they truly work in an independent manner. This Part examines whether FCC providers are independent contractors or employees for purposes of collective bargaining rights.

\section{A. A Matter of Control}

Enormously expansive in scope, the National Labor Relations Act (NLRA) extends the right to organize and join a union to any "employee," 134 with certain specific exceptions. ${ }^{135}$ Because the Act covers only private-sector employment, ${ }^{136}$ it would not apply to FCC providers even if they are classified as state employees. That said, NLRA case law provides precedential value in interpreting state labor relation laws that authorize collective bargaining for various public employees. $^{137}$ Of particular significance is case law on the

contained in the antitrust laws shall be construed to forbid the existence and operation of labor . . organizations, ... or to forbid or restrain individual members of such organizations from lawfully carrying out the legitimate objects thereof ...." Id.

133. See 29 U.S.C. § 152(3) (2000) (stating that the "term 'employee' . . shall not include . . . any individual having the status of an independent contractor").

134. See, e.g., NLRB v. Town \& Country Elec., Inc., 516 U.S. 85, 90-92 (1995) (stating that the ordinary dictionary definition of "employee" is consistent with the phrasing of the NLRA).

135. See 29 U.S.C. § 152(3) (excluding "any individual employed as an agricultural laborer, or in the domestic service of any family or person at his home, or any individual employed by his parent or spouse, or any individual having the status of an independent contractor, or any individual employed as a supervisor, or any individual employed by an employer subject to the Railway Labor Act").

136. See 29 U.S.C. § 152(2) (2000) (excluding from the definition of "employer" all federal, state, and local government entities).

137. See, e.g., Benjamin Aaron, Unfair Labor Practices and the Right to Strike in the Public Sector: Has the National Labor Relations Act Been a Good Model?, 38 STAN. L. REV. 1097, 1097 (1986) (noting that NLRB decisions have been used by state courts to interpret state statutes dealing with collective bargaining rights for public-sector employees); Rona L. Pietrzak, Some Reflections on Mackay's Application to Legal Economic Strikes in the Public Sector: An Analysis of State Collective Bargaining Statutes, 68 OR. L. REV. 87, 127 (1989) (noting that both the Montana and Vermont Supreme Courts have turned to federal case law when interpreting state statutes dealing 
aforementioned exemption of independent contractors from the NLRA's definition of employee. ${ }^{138}$

In distinguishing between employees and independent contractors, both the National Labor Relations Board (NLRB) and the courts apply general agency principles that accord considerable weight to the level of control that a company exercises over the "manner and means" by which a worker performs her job. ${ }^{139}$ Using this approach, an employment relationship exists if the employer reserves the right to control not only the result to be achieved, but also the means to be used to attain the result. By contrast, an independent contractor relationship exists where " "the employer ... reserve[s] only the right to control the ends to be achieved.", "140

While control is central to the inquiry, assessing whether an employment relationship exists depends upon other factors as well. As outlined by the Court in Nationwide Mutual Insurance Co. v. Darden, ${ }^{141}$ those factors include

the skill required; the source of the instrumentalities and tools; the location of the work; the duration of the relationship between the parties; whether the hiring party has the right to assign additional projects to the hired party; the extent of the hired party's discretion over when and how long to work; the method of payment; the hired party's role in hiring and paying assistants; whether the work is part of the regular business of the hiring party; whether the hiring party is in

with labor practices like collective bargaining).

138. By way of the Taft-Hartley Act of 1947, Congress made clear that the NLRA excludes "any individual having the status of an independent contractor." 29 U.S.C. § 152(2). For useful commentary on the Act and its legislative history, see David E. Feller, Taft and Hartley Vindicated: The Curious History of Review of Labor Arbitration Awards, 19 BERKELEY J. EMP. \& LAB. L. 296, 298 (1998); Taft-Hartley Symposium: The First Fifty Years, 47 CATH. U. L. ReV. 763 (1998). See also NLRB v. Bell Aerospace Co., 416 U.S. 267, 279-90 (1974) (discussing the Act's legislative history).

139. See, e.g., NLRB v. United Ins. Co., 390 U.S. 254, 256 (1968) (applying general agency principles to determine whether an individual is an employee or independent contractor); N. Am. Van Lines, Inc. v. NLRB, 869 F.2d 596, 599 (D.C. Cir. 1989) (stating that "[i]n applying traditional agency law principles, the NLRB and the courts have adopted a right-to-control test"); Local 777, Democratic Union Org. Comm. v. NLRB, 603 F.2d 862, 874 (D.C. Cir. 1978) (stating that "[c]ontrol exercised over the 'manner and means of performance,' . . . is the identifying characteristic of an employer/employee relationship"); In re Morton, 30 N.E.2d 369, 371 (N.Y. 1940) (observing that the distinction between an employee and an independent contractor turns on the "right of control over the [worker] in respect of the manner in which his work is to be done").

140. C.C. E., Inc. v. NLRB, 60 F.3d 855, 858 (D.C. Cir. 1995) (quoting Twin City Freight, Inc., 221 N.L.R.B. $1219,1220(1975))$.

141. 503 U.S. 318, 322 (1992). 
business; the provision of employee benefits; and the tax treatment of the hired party.

The NLRB has utilized the control test to determine whether FCC providers qualify as employees in two cases: Rosemount Center \& Rosemount Center Workers Ass' $n^{143}$ and Cardinal McCloskey's Children's \& Family Services. ${ }^{144}$

\section{Rosemount Center}

Rosemount Center involved a nonprofit child care center located in the District of Columbia. In addition to having on staff several child care teachers who worked at the Center's facilities, the Center used the services of five "family home mothers" who operated out of their own homes, providing home child care as an alternative to center-based care. ${ }^{145}$ In 1979, the NLRB granted the Rosemount Center Workers Association the right to represent the Center's workers, and an NLRB election was ordered. However, the approved voting unit excluded the family home mothers. ${ }^{146}$ The Workers Association objected to the exclusion and contended that the mothers were employees, while the Center argued that they were independent contractors and thus rightfully excluded. $^{147}$

Observing that the mothers' status depended heavily on whether the Center had "retained the right to control the manner and means" by which they accomplished their work, ${ }^{148}$ the NLRB concluded that the mothers were Center employees. In order to work for the Center, the mothers had to attend a two-week training session and were contractually obligated

to provide day care on weekdays from 7:30 a.m. to 6 p.m.; to provide suitable outdoor and indoor play areas; to provide the children with breakfast, lunch, and one afternoon snack; to provide the Employer with daily records of attendance; to regularly attend a weekly 3-hour inservice workshop on child care and development; to be present at all

\footnotetext{
142. Id. at 323-24 (quoting Cmty. for Creative Non-Violence v. Reid, 490 U.S. 730, 751-52 (1989)).

143. 248 N.L.R.B. $1322(1980)$.

144. 298 N.L.R.B. 434 (1990).

145. Rosemount Center, 248 N.L.R.B. at 1324.

146. Id. at 1322.

147. Id. at $1323-24$.

148. Id. at 1324.
} 
times while children are in this family home unless a substitute authorized by the Center is in attendance and the Center has been notified in advance of such absence; to notify the Center's social work supervisor at least 30 days in advance of any planned periodic absence, such as vacations, and such absences are not to exceed 10 days per year; to comply with all health and dietary standards and all other applicable regulations and policies promulgated by the Employer or by governmental agencies; and not to provide day care services for any child not referred by the Center, except their own children or relatives. ${ }^{149}$

In addition, the contract between the Center and the mothers specified the mothers' rate of pay indicated that the Center would provide them with training and supervision to assure that their services complied with the Center's standards, and stated that the Center would make available supplies, such as educational materials, to help the mothers. ${ }^{150}$ Given the Center's extensive control over the family home mothers' work, the NLRB readily concluded that they were employees, not independent contractors.

\section{Cardinal McCloskey's Children's \& Family Services}

Similar to Rosemount, Cardinal McCloskey involved an NLRB determination regarding the status of FCC providers who cared for children pursuant to an agreement with a nonprofit organization that operated several day care centers. The centers contracted with a New York City government agency to provide day care for families that qualified for publicly funded child care services. ${ }^{151}$ The services were provided by teachers who worked at the centers as well as by FCC providers recruited to assist the centers. ${ }^{152}$

Several factors suggested that the FCC providers were employees of the centers. The providers had to operate during certain proscribed hours; they were unable to care for children whose care was not publicly funded during those hours; they were unable to hire assistants; they were required to post schedules and menus and maintain attendance records; they had to attend mandatory training sessions; and they had to make sure their homes complied with various safety standards. ${ }^{153}$ Although these factors indicated that "the manner in which the providers furnish

\footnotetext{
149. Id.

150. Id.

151. Cardinal McCloskey's Children's \& Family Servs., 298 N.L.R.B. 434, 434 (1990).

152. Id.

153. Id. at 435-36.
} 
child care service is pervasively and meticulously supervised and controlled by the centers," "154 the NLRB ultimately ruled against the providers because the centers exercised supervision and control "pursuant to [state] regulations and guidelines." 155 The NLRB reasoned that, in requiring the providers to comply with state regulations and guidelines, the centers were functioning "merely as conduits" and were not themselves controlling "the manner and means of the providers' operations." $" 156$

The intermediary role that the McCloskey centers played between the FCC providers and the City of New York distinguishes Rosemount and McCloskey. The control that the Rosemount Center exercised over its FCC providers stemmed from center-imposed rules, but in McCloskey, the control originated with the City of New York, and the centers simply acted to ensure that the FCC providers complied with those rules. ${ }^{157}$ Of course, while this distinction meant that the McCloskey providers did not qualify as center employees, it raised the possibility that they were employees of the City of New York. The NLRB in McCloskey acknowledged this possibility, without offering additional commentary. ${ }^{158}$

\section{B. The Analogy of Home Care Workers}

Rosemount and McCloskey offer useful starting points to evaluate when a FCC provider may qualify as an employee for purposes of collective bargaining. However, their utility is limited given that both cases dealt with private-sector employment. To initiate a more precise analysis of the issue as it applies to public-sector employment, SEIU's campaign to organize home care workers in California again comes into play.

154. Id. at 436 .

155. Id.

156. See id. at 436-37 (commenting that "because the centers' supervision of the providers is effectively limited to ensuring that [state regulatory] requirements are met, the record does not indicate that the centers themselves control the manner and means of the providers' operations"; in addition, "the centers [do not] exert authority over the providers that exceeds in any meaningful way the controls imposed by [state] regulations"); see also Local 777, Democratic Union Org. Comm. v. NLRB, 603 F.2d 862, 875 (D.C. Cir. 1978) (commenting that "[g]overnment regulations constitute supervision not by the employer but by the state").

157. The status of FCC providers under the NLRA was also at issue in Valley Special Needs Program, Inc., No. 6-CA-24051, 1993 WL 1609563 (N.L.R.B. Dec. 16, 1993), adopted as modified by 314 N.L.R.B. 903 (1994), where the court concluded that FCC providers were independent contractors on facts similar to those in McCloskey.

158. See McCloskey, 298 N.L.R.B. at 438 n.18 ("It is not necessary ... to consider whether the providers are employees of the city of New York. Accordingly, we do not reach that issue.”). 
As with child care, a great deal of home care is publicly funded. ${ }^{159}$ In California, for example, individuals who qualify for governmentfunded home care services can select a home care provider whose services are paid for by the government. ${ }^{160}$ The SEIU emphasized the public character of home care in its bid to have the workers classified as government employees. When the purported employer-the County of Los Angeles - refused to negotiate with the SEIU, legal action was commenced against the County. At issue in the ensuing case, Service Employees International Union, Local 434 v. County of Los Angeles, ${ }^{161}$ was whether publicly funded home care workers were employees of the County under the Meyers-Milias-Brown Act (MMBA), ${ }^{162}$ the California law governing labor relations for local government employees. ${ }^{163}$

In support of its position, the SEIU relied upon two earlier cases involving the legal status of California home care workers: ${ }^{164}$ Bonnette $v$. California Health \& Welfare Agency ${ }^{165}$ and In-Home Supportive Services v. Workers' Compensation Appeals Board. ${ }^{166}$ Bonnette held that government agencies of the State of California, which administered the home care services program, were employers of the workers for purposes of the Fair Labor Standards Act. ${ }^{167}$ Specifically, the Bonnette court observed that the agencies "exercised considerable control over the nature and structure of the employment relationship."168 In In-Home Supportive Services, the court held that the home care workers were state employees under California's workers' compensation law, and thus eligible for benefits for an injury sustained in the course and scope of employment. ${ }^{169}$ In rendering its decision, the court stated that " $[\mathrm{t}] \mathrm{he}$

159. See Delp \& Quan, supra note 9, at 2 ("The majority of homecare workers in California is paid through an agency of the state government ....").

160. Id. at 3 (stating that "consumers directly hire ... the workers who care for them" and "the state IHSS issues the paychecks").

161. 275 Cal. Rptr. 508 (Ct. App. 1990)

162. CAL. Gov’T CODE $\S \S 3500-3511$ (West 1995 \& Supp. 2006); see also id. $\S 3505$ (requiring local governments to "meet and confer in good faith regarding wages, hours, and other terms and conditions of employment with representatives of . . recognized employee organizations").

163. Serv. Employees Int'l Union, 275 Cal. Rptr. at 510.

164. Id. at 511-12.

165. 704 F.2d 1465 (9th Cir. 1983)

166. 199 Cal. Rptr. 697 (Ct. App. 1984).

167. See Bonnette, 704 F.2d at 1470 (applying the Fair Labor Standards Act, 29 U.S.C. $\S \S 201-$ 19 (2002), and concluding the workers were employees).

168. Id.; see also id. (observing that the state agencies "controlled the rate and method of payment, and that they maintained employment records. . . . [The agencies] also exercised considerable control over the structure and conditions of employment by making the final determination, after consultation with the recipient, of the number of hours each [home care] worker would work and exactly what tasks would be performed.").

169. See In-Home Supportive Servs., 199 Cal. Rptr. at 702 (concluding that the relationship was 
county, under the regulatory scheme, has the right to sufficient control over the [home care worker] to make the state chargeable, by virtue of the agency relationship with the state, as an employer." ${ }^{, 170}$

In Service Employees International Union, the California Court of Appeal concluded that these decisions were not dispositive as both involved statutes other than the MMBA. ${ }^{171}$ Despite a vigorous dissent, ${ }^{172}$ the court ultimately ruled against the SEIU, and affirmed the lower court's decision, which had emphasized that:

[t]he county exercises no supervisory control over [home-care] providers. The manner in which the provider's tasks are performed is determined by the recipient, as are the hours when such services are performed. The provider is free to terminate his or her services without notice to the county; likewise, a recipient may discharge a provider at any time without notice to the county. If a provider is not performing satisfactorily the county has no right to intervene. Where the recipient's health or safety is endangered by such unsatisfactory

that of employer and employee).

170. Id. at 703 (italics omitted).

171. Serv. Employees Int'l Union, Local 434 v. County of L.A., 275 Cal. Rptr. 508, 512 (Ct. App. 1990). The court's opinion highlights the lack of uniformity within federal law to determine who is or is not an employee. For example, while the NLRA adopts a narrow approach to evaluate the existence of an employment relationship, the FLSA adopts a much broader approach. Compare Aetna Freight Lines, Inc. v. NLRB, 520 F.2d 928, 930 (6th Cir. 1975) (stating that the test under the NLRA is the "right to control test"), with Bonnette, 704 F.2d at 1469 (employing the "economic reality test" under the FLSA). This lack of uniformity has drawn considerable criticism from both courts and commentators. As the Third Circuit observed:

Even when the same person performs the same acts at the same time in the same place under the same conditions conceivably he could not be considered an employee under some common law standards and some federal statutory definitions while he nevertheless could be considered an employee under those of others. This absence of a universality in qualities and definition unavoidably breeds ambiguity and confusion requiring courts to assess a broad spectrum of facts in their quest to clarify and determine who is and who is not an employee.

EEOC v. Zippo Mfg. Co., 713 F.2d 32, 35-36 (3d Cir. 1983); see also REPORT \& RECOMMENDATION OF THE COMMISSION ON THE FUTURE OF WORKER-MANAGEMENT RELATIONS 36, 38 (1994) [hereinafter REPORT ON FUTURE OF WORKER-MANAGEMENT RELATIONS] (proposing the adoption of a unitary "economic realities" test for defining employee status to be "appl[ied] ... across the board in employment and labor law"); Nancy E. Dowd, The Test of Employee Status: Economic Realities and Title VII, 26 WM. \& MARY L. REV. 75, 89-95 (1984) (discussing the varied understandings of "employee" in federal employment and labor laws); Jonathan P. Hiatt, Policy Issues Concerning the Contingent Work Force, 52 WASH. \& LEE L. REV. 739, 750 (1995) (arguing that "there should be a single definition applicable in all employment and labor law contexts that would recognize the distinction between an employee and an independent contractor in a more direct, less manipulable manner").

172. See Serv. Employees Int'l Union, 275 Cal. Rptr. at 524 (Johnson, J., dissenting) (stating that "the county has the right to control the activities of the IHSS providers whether it exercises it or not"). 
performance, the county's only recourse is to place the recipient in an appropriate facility.

Under general common law agency principles, the court in Service Employees International Union arguably reached the correct decision. Apart from compensating the workers, the public agencies had few regulations in place that affected job performance. ${ }^{174}$ As the court noted, the right to supervise the workers rested with the individual recipients of the services. ${ }^{175}$

\section{Family Child Care Providers as Employees: The Case of Rhode Island}

To date, it appears that only one state, Rhode Island, has seriously grappled with whether FCC providers qualify as public employees entitled to collective bargaining rights. Under the Rhode Island Child Care Assistance Program, ${ }^{176}$ working families that earn at or below 225 percent of the federal poverty level are entitled to child care assistance. ${ }^{177}$ If a family is approved for assistance, the state issues a voucher that can be used for any approved child care provider, including an FCC provider operating a "family day care home."178 In 2002, Rhode Island licensed approximately 1516 child care providers, ${ }^{179}$ and of that number, 1071 qualified as family child care homes. ${ }^{180}$

To operate a family day care home in Rhode Island, a provider must be licensed by the state, which requires compliance with an extensive set of regulations "governing character, health, suitability, and qualifications; provider/child ratios; workload assignments; procedures

173. Id. at 511 (majority opinion).

174. Id. at 510-11.

175. Id. at 511 .

176. R.I. GEN. LAWS § 40-5.1-17 (Supp. 2005).

177. See id. § 40-5.1-17(a) (“[E]ffective July 1, 1999, the department shall provide appropriate child care to such other families whose incomes are at or below two hundred twenty-five percent (225\%) of the federal poverty line."). Rhode Island is the only state that statutorily guarantees the provision of child care assistance to all working families with incomes below a certain threshold. $I d$. $\S 40-5.1-17$.

178. R.I. GEN. LAWS $\S 42-72.1-2(10)$ (1998) (defining a family day care home as "any home other than the child's home in which child day care in lieu of parental care and/or supervision is offered at the same time to four (4) or more children who are not relatives of the care giver").

179. Charles J. Quigley \& Elaine M. Notarantonio, The Economic Impact of Rhode ISLAND's CHILD CARE INDUSTRY 4 (2003), available at http://www.ripolicyanalysis.org/ BryantReport.pdf.

180. Id. at 5 . 
and practices regarding basic child care and services; and compliance with fire and safety codes." ${ }^{\text {"181 }}$ For example, to become licensed, an applicant must attend a three-hour orientation session, ${ }^{182}$ submit a physician's statement documenting that she is in good health, comply with a criminal background check and place her fingerprints on file with the appropriate local enforcement authority, have her home approved by the fire inspector and by the health department to ensure compliance with state fire codes and applicable health and safety standards, ${ }^{183}$ and pass a home inspection from the state's Department of Children, Youth and Family Services to ensure the home's suitability as well as the suitability of all household members. ${ }^{184}$ Other regulations specify the type of discipline that providers can use ${ }^{185}$ restrict providers' ability to engage in other forms of employment, ${ }^{186}$ require providers to attend periodic training sessions, ${ }^{187}$ and require providers to submit to unannounced home visits. ${ }^{188}$

In 2004, SEIU Local 1199, together with the Rhode Island Day Care Justice Co-operative, an organization that represented the interests of over 1000 FCC providers, petitioned the Rhode Island Labor Board (RILB) to allow the union to represent the providers pursuant to the Rhode Island State Labor Relations Act. ${ }^{189}$ The SEIU identified various Rhode Island state agencies as the providers' employers. In hearings before the RILB, the state agencies objected to the formation of a bargaining unit, arguing that they did not employ the providers. ${ }^{190}$ In its decision, the RILB agreed with the union, holding that the providers were state employees and issuing an order to give them the right to decide whether to unionize. ${ }^{191}$ Unfortunately for the providers, the

\footnotetext{
181. New Eng. Health Care Employees Union, Local 1199, No. EE- 3671, Home Daycare Providers, at 3 (R.I. State Labor Relations Bd. 2004), available at http://www.dlt.state.ri.us/lrb/pdfs/ DecisionEE3671.pdf.

182. Id.

183. Id. at 4.

184. Id.

185. Id.

186. See id. ("DCYF prohibits providers from engaging in other employment while children are in their care and from having children in their care on the morning following all-night employment.").

187. See id. ("Providers must demonstrate and document ten hours of approved training every two years and must re-certify every two years.").

188. See id. ("DCYF social workers are authorized to make unannounced visits to providers' homes to investigate compliance with DCYF regulations.").

189. Id. at 1 . The Rhode Island State Labor Relations Act is codified in R.I. GEN. Laws $\S \S 28-$ 7-1 to $-7-48$ (2003)

190. New Eng. Health Care Employees Union, No. EE- 3671, at 1.

191. Id. at 32-33.
} 
Rhode Island Superior Court reversed the RILB's decision. ${ }^{192}$ Taken together, the two decisions highlight the difficulty of trying to determine when FCC providers qualify as employees.

For the RILB, the state's "pervasive regulatory presence in the . . . home[s]"193 of providers proved determinative:

[T] he State controls virtually every aspect of providers' jobs. It controls who becomes a provider; providers' home and work environments; the number of children they may care for; what they may feed the children; daily routines with the children; methods of discipline; relationships with assistants, if any; and providers' relationships with parents. Further, the Employer places limits on the providers' work schedules, supervises and reviews providers' activities by requiring them to submit attendance records, requires providers to notify the Employer of any changes in their location, status or other information and requires providers to maintain specific files on each child. Financial records must also be kept for a specified period of time .... [T] [Te Employer has unfettered access to providers' homes when a complaint has been raised. ${ }^{194}$

The state's level of control over the manner and means by which the providers performed their work was so great, reasoned the RILB, that it "inexorably" led to the conclusion that they were employees and not independent contractors. ${ }^{195}$

The majority remained confident in its decision even as three members of the seven-person RILB dissented from the opinion. As the dissent saw it, it was impossible for the state to exercise sufficient control over the work of the providers to render them employees given the location of the work within the providers' homes. ${ }^{196}$ The dissent raised an important point that deserves further explication. As noted above, ${ }^{197}$ the location of the work is one of many factors involved in determining whether an employment relationship exists. This factor is especially important to family child care because the work occurs within

192. State v. State Labor Relations Bd., No. C.A. 04-1899, 2005 WL 3059297, at *8 (R.I. Super. Ct. Nov. 14, 2005).

193. New Eng. Health Care Employees Union, No. EE- 3671, at 25.

194. Id. at 28 .

195. Id. The RILB's conclusion that the FCC providers were employees also rested on the limited skill required for an individual to work as a provider, the provision of employee benefits to providers, and the integral nature of providers' work to the state agencies. Id. at 13, 21-22.

196. Id. at 2 (Goldstein, dissenting) ("Services are not provided in state owned (or state rented) homes. The state cannot observe the same conditions that exist in commonly used state properties .. ..").

197. See supra notes 141-42 and accompanying text (outlining the factors used to determine whether an employer-employee relationship exists). 
the private sphere of the home. Under the common law of agency, the location of work is intricately linked to the level of control that a putative employer exercises. The law usually ascribes independent contractor status to individuals who work at home, or who otherwise labor at a location remote from that of the putative employer, since they are not subject to the control that comes with day-to-day supervision. ${ }^{198}$

Yet while the state did not exercise direct control over the FCC providers, it exercised far greater control over them than that which is typical of home-based workers. As the majority observed, a provider who cares for a child receiving subsidized care in Rhode Island stands in stark contrast to a "true independent contractor" with a home-based work site such as a home office, whose workspace is seldom, if ever, subject to regulation or inspection by the company with whom she does business. ${ }^{199}$ By contrast, Rhode Island heavily regulates the homes of FCC providers who provide care for subsidized children:

[H]omes must have 35 square feet of play/work space available for each child within the home; there must be an area for outdoor play which is safe from hazards; there are limitations on the use of porches above the first floor; there must be a separation of functions from room to room; hot water may not be set higher than 120 degrees; electrical outlets must be covered when not in use; the heating system must be capable of maintaining a minimum temperature of 65 degrees; there must be a working telephone at all times; emergency phone numbers must be posted and clearly visible; there must be a first aid kit on the premises with a specific inventory of items; there must be an emergency evacuation plan and it must be practiced monthly; the refrigerator must be maintained at 45 degrees or less; drugs, medicines and cleaning materials must be stored in specific [containers, and] stairways must be gated; doors and windows must be securely screened; no peeling paint or plaster is permitted and domestic animals must be vaccinated and away from the children. ${ }^{200}$

198. See Joan T.A. Gabel \& Nancy R. Mansfield, The Information Revolution and Its Impact on the Employment Relationship: An Analysis of the Cyberspace Workplace, 40 AM. BUS. L.J. 301, 347 (2003) (discussing the rise of home-based computer workers and considering whether they are independent contractors under the NLRA); Michael C. Harper, Defining the Economic Relationship Appropriate for Collective Bargaining, 39 B.C. L. REV. 329, 335 (1998) (observing that the right-tocontrol test enables employers "to exclude from the Act's coverage workers, such as traveling sales personnel, delivery drivers and taxicab drivers, whose mobility makes direct supervision infeasible"); Hiroshi Motomura, Comment, Employees and Independent Contractors Under the National Labor Relations Act, 2 IndUS. ReL. L.J. 278, 289 (1977) (citing Am. Broad. Co., 117 N.L.R.B. 13, 18 (1957)) (discussing the NLRB's conclusion that musicians, who worked out of their own homes, were independent contractors because supervision was absent).

199. New Eng. Health Care Employees Union, No. EE- 3671, at 15.

200. Id. at $14-15$. 
Thus, even as the providers were not subject to day-to-day supervision, the state nevertheless tightly controlled the manner and means of their work, as well as their working environment.

On appeal, the Superior Court brushed over this point, concluding with little explanation that the state's authority over FCC providers equated not with control but simply with the power to enforce compliance with regulatory rules. ${ }^{201}$ Such a distinction is clearly warranted in certain contexts as, for example, in the earlier discussion of McCloskey where the child care centers at issue functioned as conduits to ensure that the centers' FCC providers complied with state regulations. ${ }^{202}$ In a situation, however, where the state is itself the alleged employer, as opposed to a third party as was true in McCloskey, the question remains as to whether the state, by way of its regulations, effectively controls the manner and means of the providers' operations. Unfortunately, the court ignored this question.

However, even if the Rhode Island FCC providers had prevailed before the court, the control test is ultimately far too unpredictable to assure a favorable outcome for other licensed FCC providers who lack control over how they perform their work. Fraught with uncertainty and difficulty, the control test is often a poor measure for determining employee or independent contractor status. ${ }^{203}$ As numerous commentators have remarked, application of the control test often serves to deny collective bargaining rights to workers who lack adequate individual bargaining leverage and thus need protection under applicable collective bargaining statutes. ${ }^{204}$

201. State v. State Labor Relations Bd., No. C.A. 04-1899, 2005 WL 3059297, at *7 (R.I. Super. Ct. Nov. 14, 2005)

202. See supra notes $151-58$ and accompanying text

203. See, e.g., Richard R. Carlson, Why the Law Still Can't Tell an Employee When it Sees One and How it Ought to Stop Trying, 22 Berkeley J. EMP. \& LAB. L. 295, 361 (2001) (observing that "the control test sometimes leads to uncertain results, because an employer's control over one aspect of the employment relationship may be offset by a lack of control over some other aspect"); id. at 340 (commenting that "the degree and nature of employer control is hopelessly elusive"); Dowd, supra note 171, at 85 (commenting that the control test "fails to distinguish between an individual who essentially contracts with the employer from a relatively equal bargaining position and the worker who is involved in an ongoing relationship in which significant direct or indirect control is retained by the employer. In the latter relationship, bargaining power with respect to the terms and conditions of employment rests almost entirely with the employer."); Hiatt, supra note 171, at 74950 (discussing how companies engaged in contract hiring manipulate the control test); Motomura, supra note 198, at 295 (commenting that the right-to-control test has failed to yield "a coherent, well-formulated set of principles for distinguishing independent contractors and employees").

204. See, e.g., Hiatt, supra note 171 , at 739 (commenting on the classification of "minimumwage" home care workers as independent contractors); Marc Linder, Towards Universal Worker Coverage Under the National Labor Relations Act: Making Room for Uncontrolled Employees, Dependent Contractors, and Employee-Like Persons, 66 U. DET. L. REV. 555, 594-96 (1989) 
FCC providers who deliver subsidized care would stand a far better chance of being classified as employees if collective bargaining rights hinged not on the control test, but on a test that accorded centrality to the economic status of the worker vis-à-vis her relationship with a putative employer. In NLRB v. Hearst Publications, Inc., ${ }^{205}$ the Supreme Court articulated such an approach to govern the determination of an employee under the NLRA. ${ }^{206}$ The approach, often referred to as the economicreality test, recognizes that workers, such as FCC providers who work at home, can still be economically dependent on the entities for which they work, "even absent traditional looking-over-the-shoulder physical control." 207

Evaluated in terms of economic dependence, it becomes clear that FCC providers who deliver subsidized care far more closely resemble employees than independent contractors. Importantly, they lack the type of attributes typically associated with independent contractors. They neither have access to the means of production that would enable them to function as capitalists nor do they possess a scarce marketable skill. ${ }^{208}$ As noted earlier, such providers are overwhelmingly poor and rarely viewed as skilled workers. ${ }^{209}$ Unlike an independent contractor, whose income is based upon profits realized from capital, state-paid FCC providers primarily function as wage laborers. They offer only their services, caring for children, in exchange for a wage from the state, and they lack the bargaining power to ensure that the wages received are reasonable.

While the economic-reality test was short-lived under the NLRA, ${ }^{210}$ it is arguably far more consistent than is the control test, with collective bargaining's goal of redressing the fundamental inequality of bargaining

[hereinafter Linder, Toward Universal Worker Coverage] (discussing how taxi companies manipulate the control test to deny collective bargaining rights to leased taxi drivers); Marc Linder, What Is an Employee? Why It Does, But Should Not, Matter, 7 LAW \& INEQ. 155, 181-82 (1989) [hereinafter Linder, What Is an Employee?] (listing groups of workers with limited bargaining power who may be classified as independent contractors and thus excluded from the protection of labor laws).

205. 322 U.S. 111 (1944).

206. See id. at 129 (stating that the NLRB, when making a determination, should consider the "underlying economic facts rather than ... [making a determination] technically and exclusively by previously established legal classifications").

207. Linder, Toward Universal Worker Coverage, supra note 204, at 601.

208. Linder, What Is an Employee?, supra note 204, at 162.

209. See supra notes 70-74, 87-89 and accompanying text (discussing the economic status and social perceptions of FCC providers).

210. Congress expressed its clear disapproval of the Hearst decision and its use of the economicreality test in enacting the Taft-Hartley Amendments. See supra note 138; see also Carlson, supra note 203, at 321-25 (discussing the congressional response to Hearst). 
power between workers and management. Developed as a tort law principle, the control test's distinction between employees and independent contractors represents a rational approach for assessing "whether a firm has vicarious liability for the wrongs committed by those who may be advancing the firm's interests." 111 However, "[a]s a test for determining which workers should be able to bargain collectively with a firm whose interests they advance, . . . it [often] makes no sense at all., ${ }^{212}$ By anchoring the employee-independent contractor distinction on who controls the manner and means of work, the test provides an incentive for businesses to manipulate work settings so as to give workers superficial control, such that they no longer qualify as rightsbearing employees. ${ }^{213}$ Yet all too often, the business retains the power to determine the terms and conditions of the working relationship. ${ }^{214}$

As Professor Marc Linder queries, "[a]s long as employers control the working conditions that workers want improved, why should it matter whether they tell them how to work?"215 This Article echoes Linder's position that it should not matter. Even if FCC providers are in some sense entrepreneurial, as economically marginalized workers, they should still enjoy collective bargaining rights under applicable state collective bargaining laws. While the economic-reality test is far more amenable to this proposition than the control test, commentators point out that it also involves uncertainty in its application. ${ }^{216}$

An alternative approach is to create a dependent contractor category that would confer collective bargaining rights on workers who are "economically so dependent on the entities for which they work that they

211. Harper, supra note 198, at 334; see also Dowd, supra note 171, at 98-100 (discussing the control test's historical foundation as a tort law concept).

212. Harper, supra note 198, at 334; see also REPORT ON FUTURE OF WORKER-MANAGEMENT RELATIONS, supra note 171, at 37 (commenting that the test "is based on a nineteenth century concept whose purposes are wholly unrelated to contemporary employment policy").

213. Harper, supra note 198, at 334-35.

214. Marc Linder, Dependent and Independent Contractors in Recent U.S. Labor Law: An Ambiguous Dichotomy Rooted in Simulated Statutory Purposelessness, 21 COMP. LAB. L. \& POL'Y J. 187, 198 (1999).

215. Id. at 201; see also Carlson, supra note 203, at 299 ("The difficulty of defining 'employee' . . . leads to what ought to have been the first question for legislators: why should employee status matter at all?").

216. See Carlson, supra note 203, at 342 ("The economic realities test certainly allows the inclusion of some workers within a modern meaning of 'employee,' but the test is no more predictable, and probably less so, than a simple control test."); Lewis L. Maltby \& David C. Yamada, Beyond "Economic Realities": The Case for Amending Federal Employment Discrimination Laws to Include Independent Contractors, 38 B.C. L. REV. 239, 262 (1997) ("[T]he economic realities test is an improvement on the common-law test, but it does not go far enough in recognizing the structural changes in the American workforce and protecting the growing number of workers who do not fall into older, more traditional patterns of employment."). 
are effectively precluded from competing as capital accumulators."217 Such an approach recognizes that even though some workers may not fit the traditional definition of an employee, they also do not possess the type of skill, capital, or bargaining power that characterizes independent contractors. Designation of an FCC provider as a dependent contractor would enable her, in conjunction with other providers, to bargain with the state to achieve socially acceptable terms and conditions of the labor relationship.

Absent the creation of a dependent contractor category, FCC providers who serve families receiving subsidized child care are left with the uncertainty of the control test, and the limited likelihood that courts will look favorably upon claims that they are essentially de facto state employees. Consequently, as a practical matter, labor should consider alternative approaches to organize and represent FCC providers. The next Part examines one such approach that has met with considerable success.

\section{AN EMPLOYER-OF-RECORD APPROACH}

Although antitrust law generally prohibits independent contractors from engaging in collective bargaining, such bargaining may be permissible if approved by the state. Articulated in Parker v. Brown, ${ }^{218}$ the state-action doctrine allows states to carve out immunities from the federal antitrust statutes. ${ }^{219}$ Thus, an alternative avenue to organize and represent FCC providers is to press for legislation granting providers collective bargaining rights despite the absence of a traditional employment relationship. The legislation would designate a state agency as an employer of record for FCC providers for the purpose of collective bargaining. In order to qualify for the state-action exemption, the legislation must satisfy a two-prong test. ${ }^{220}$ First, it must affirmatively

217. Linder, Toward Universal Worker Coverage, supra note 204, at 601; see also Maltby \& Yamada, supra note 216, at 266 (suggesting a comparable approach in the context of discrimination statutes such that independent contractors would be covered); Charles J. Morris, A Blueprint for Reform of the National Labor Relations Act, 8 ADMIN. L.J. AM. U. 517, 562 (1994) ("[I]t might be appropriate to provide express coverage of 'dependent contractors' where the individuals involved exhibit a dependent economic relationship to a single company not unlike that of wage-earners."); Henry H. Perritt, Jr., Should Some Independent Contractors Be Redefined as "Employees" Under Labor Law?, 33 VILL. L. REV. 989, 1032-34 (1988) (discussing the "dependent contractor" concept in Canadian law).

218. 317 U.S. 341 (1943).

219. Id. at 351. See generally Phillip E. AREedA \& HERBERT HovenKAMP, I ANTITRUST LAW (2d ed. 2000) (explaining "state action" immunity).

220. See Cal. Retail Liquor Dealers Ass'n v. Midcal Aluminum, Inc., 445 U.S. 97, 105 (1980) 
express a clearly articulated state policy to supplant competition with a regulatory scheme. ${ }^{221}$ Second, the legislation must provide for adequate and active state supervision to ensure that the antitrust immunity represents the state's own interests, and not merely those of a private party. ${ }^{222}$

\section{A. Home Care Workers: Charting the Path}

Use of the state-action doctrine to secure bargaining rights for lowwage service workers, deemed independent contractors, gained prominence in the context of the aforementioned SEIU campaign to organize California home care workers. Following its unsuccessful attempt to persuade the California courts that home care workers were employees under the MMBA, ${ }^{223}$ SEIU turned to the state legislature. After months of coalition lobbying by SEIU and various consumer groups, ${ }^{224}$ the California legislature passed a law in 1992 that authorized each county in the state to create "public authorities"-agencies that would serve as the legal employer for the home care workers within the county with respect to state collective bargaining laws. ${ }^{225}$ In 1997, pursuant to the law, Los Angeles County created a public authority that functions as the employer of record for the county's home care workers. ${ }^{226}$

Two years later, SEIU achieved the largest union victory in the United States since 1941 when it successfully organized 74,000 home

(setting forth two standards for antitrust immunity), overruled in part by Hallie v. Eau Claire, 471 U.S. 34, 46 (1985) ("[T] he active state supervision requirement should not be imposed in cases in which the actor is a municipality."); see also S. Motor Carriers Rate Conference, Inc. v. United States, 471 U.S. 48, 57-62 (1985) (holding the two-prong test applicable to private party claims of state-action immunity).

221. Midcal, 445 U.S. at 105 (citing City of Lafayette v. La. Power \& Light Co., 435 U.S. 389, 410 (1978).

222. See S. Motor Carriers Rate Conference, 471 U.S. at 56-57 ("This supervision requirement prevents the State from frustrating the national policy in favor of competition by casting a 'gauzy cloak of state involvement' over what is essentially private anticompetitive conduct." (quoting Midcal, 445 U.S. at 106)).

223. See supra notes 161-75 and accompanying text (discussing SEIU's attempts to convince the California courts that home care workers were state employees).

224. See HEINRITZ-CANTERBURY, supra note 9, at 11 (identifying key groups lobbying for the legislation: the SEIU and members of the disability and senior communities).

225. CAL. WELF. \& INST. CODE § 12301.6 (West Supp. 2006). In 1999, the California legislature enacted a law that required all California counties to "act as or establish an employer" for IHSS workers. CAL. WELF. \& INST. CODE $§ 12302.25(a)$ (West Supp. 2006).

226. Delp \& Quan, supra note 9, at 11. 
care workers in Los Angeles. ${ }^{227}$ Between 2000 and 2003, SEIU organized a total of 290,000 home care workers throughout the country. ${ }^{228}$ The home care campaign has achieved tangible successes. For example, a recent study of unionization effects on home care in San Francisco indicates that the wages of workers have almost doubled, and job turnover has dropped significantly. ${ }^{229}$ In Oregon, unionization has led to paid health insurance for workers, paid vacation time, increased wages, and coverage under the state's workers compensation system. ${ }^{230}$

\section{B. Success in Illinois}

In 2005, Illinois became the first state to pass legislation that extends bargaining rights to FCC providers and immunizes them from federal antitrust liability. ${ }^{231}$ In February 2005, the Governor of Illinois signed an executive order ${ }^{232}$ granting collective bargaining rights to FCC providers under the Illinois Public Labor Relations Act, ${ }^{233}$ and immunizing their bargaining activity from antitrust liability. ${ }^{234}$ Later that year the Illinois legislature passed a law that echoed the sentiments of the executive order and provided that:

[F]or the purposes of coverage under the Illinois Public Labor Relations Act, child and day care home providers, including licensed

227. Id. at 2; Schneider, supra note 115 , at 26 .

228. Serv. Employees Int'l Union, SeIU Health Care Division Report, Building a NATIONAL MOVEMENT FOR QUALITY CARE 3 (2004), available at http://www.seiu1984.org/ appResources/scDocs/HealthDivision.Rpt.pdf; see also Schneider, supra note 115, at 27 (noting the unionization of "almost 300,000 home care workers" in California, Oregon, and Washington).

229. Candace Howes, Upgrading California's Home Care Workforce: The Impact of Political Action and Unionization, in THE STATE OF CALIFORNIA LABOR, 2004, at 71, 92-98 (2004), available at $\mathrm{http} / /$ repositories.cdlib.org/cgi/viewcontent.cgi?article=1039\&context=ile; see also Patrice M. Mareschal, Agitation and Control: A Tactical Analysis of the Campaign Against New Jersey's Quality Home Care Act (May 21, 2005) (presented at the Caring Labor Conference, Harry Bridges Center for Labor Studies), available at http://www.depts.washington.edu/pcls/Mareschalpaper.pdf ("Unionization and the establishment of public authorities have produced a substantial improvement in pay and benefits throughout Washington and Oregon, as well as in California's larger cities and suburbs.").

230. Schneider, supra note 115 , at 26.

231. 305 ILl. Comp. Stat. AnN. 5/9A-11(b-5) (West Supp. 2006).

232. Exec. Order No. 2005-1, 29 Ill. Reg. 3386 (Feb. 18, 2005).

233. 5 Ill. Comp. StAT. ANN. 315/1 (West 2005). For useful commentary on the law, see Barbara Rose, Union for Child-care Workers, CHI. TRIB., Apr. 8, 2005, at C1 (discussing the Illinois child care providers' election to join SEIU). See also Brooks, supra note 122, at 52-53 (discussing SEIU's work on behalf of FCC providers before the State of Illinois officially recognized the order and the governor signed the executive order).

234. Exec. Order No. 2005-1, 29 Ill. Reg. at 3387. 
and license exempt, participating in the Department's child care assistance program shall be considered to be public employees and the State of Illinois shall be considered to be their employer . . . . The State shall engage in collective bargaining with an exclusive representative of child and day care home providers participating in the child care assistance program concerning their terms and conditions of employment that are within the State's control. ${ }^{235}$

Notably, the law applies to both licensed and license-exempt providers who participate in the state's child care assistance program. ${ }^{236}$ Under the law, the state is regarded as the employer of FCC providers solely for the purpose of collective bargaining. ${ }^{237}$ As mandatory subjects of bargaining include "any matter with respect to wages, hours and other conditions of employment, not specifically provided for in any other law or not specifically in violation of the provisions of any law, ${ }^{238}$ FCC providers now have the right to participate in the determination of provider reimbursement rates.

The Illinois legislature was careful to satisfy the first requirement of the state-action doctrine by expressing the state's clear intent to displace market competition with a regulatory scheme: "In according child and day care home providers and their selected representative rights under the Illinois Public Labor Relations Act, the State intends that the State action exemption to application of federal and State antitrust laws be fully available . . .."239 Under the second prong of the state-action doctrine, state officials must "have and exercise power to review particular anticompetitive acts of private parties and disapprove those that fail to accord with state policy."240 The legislation also satisfies this prong as the state will be involved in negotiations with a representative of the FCC providers, and any collective bargaining agreement reached must necessarily have met with the state's approval. ${ }^{241}$

235. 305 Ill. Comp. Stat. AnN. 5/9A-11(b-5) (West Supp. 2006).

236. 5 Ill. COMP. Stat. ANN. 315/3(f) (West Supp. 2006).

237. See id. 315/3(o) ("The State shall not be considered to be the employer of child and day care home providers for any purposes not specifically provided in this amendatory Act . . . including but not limited to, purposes of vicarious liability in tort and purposes of statutory retirement or health insurance benefits.").

238. Id. $315 / 7$.

239. 305 Ill. Comp. StAT. ANN. 5/9A-11(c) (West Supp. 2006).

240. Patrick v. Burget, 486 U.S. 94, 100-01 (1988).

241. As Professor Herbert Hovenkamp points out, the supervision prong requires that "the state itself, rather than a private party, is the effective decision maker." AREEDA \& HOVENKAMP, supra note 219, at 477. Even as it is to be expected that FCC providers will have staked out their position on issues of importance before heading to the bargaining table, the ultimate agreement can properly be regarded as the "State's own" since the collective bargaining process ensures that the State has 
Following enactment of the law, 49,000 FCC providers in Illinois elected to have the SEIU represent them in negotiations with the state. ${ }^{242}$ The election, which was the second largest union victory achieved since 1941, was the largest child care election in United States history. ${ }^{243}$ In December 2005, the providers announced the details of their first contract with the state. ${ }^{244}$ Key provisions of the contract include access to affordable health care for providers, ${ }^{245}$ incentives for providers to acquire training in early education, ${ }^{246}$ and an increase in the reimbursement rate paid to FCC providers. ${ }^{247}$

Both SEIU and AFSCME are pursuing a comparable strategy to organize and represent FCC providers in other states, including California, Maryland, Massachusetts, Michigan, Minnesota, New Jersey, Ohio, Pennsylvania, and Wisconsin. ${ }^{248}$ Thus far, governors in two additional states, Oregon ${ }^{249}$ and Iowa, ${ }^{250}$ have signed executive orders

"played a substantial role in determining the specifics of the economic policy." FTC v. Ticor Title Ins. Co., 504 U.S. 621, 635 (1992).

242. Comerford \& Huq, supra note 71, at 1; Rose, supra note 233, at C1.

243. Comerford \& Huq, supra note 71, at 1.

244. Press Release, Serv. Employees Int'l Union, 49,000 Family Child Care Providers Negotiate Historic Contract in IL to Raise Standard for Quality Care Services (Dec. 13, 2005), http:// www.seiu.org/media/pressreleases.cfm?pr_id=1275 [hereinafter SEIU Press Release]; see also Stephen Franklin, Illinois Agrees to Labor Pact on Child Care, CHI. TRIB., Dec. 13, 2005, at 3.

245. See SEIU Press Release, supra note 244 ("The state and the union will work together to determine eligibility requirements and plan details. The state has committed to a \$27 million investment in funding in year three of the contract.").

246. See id. ("Incentives for additional training in early education - up to 20 percent in extra pay to encourage providers to enhance their effectiveness as early educators and improve school readiness.").

247. See id. ("Rate hikes to stem turnover-providers' base subsidy rates - which now are as low as $\$ 9.48$ per child per day-will increase an average of 35 percent over the three years of the contract to help encourage qualified providers to enter and stay in child care.").

248. Serv. Employees Int'l Union, Illinois Child Care Victory, www.seiu.org/public/child_care/il_providers_unite.cfm (last visited Oct. 18, 2006).

249. Exec. Order No. 05-10, 44-11 Or. Bull. 4 (Nov. 1, 2005). The executive order provides that

[t]he Director of the Department of Human Services and the Director of the Employment Department ... shall meet and confer with AFSCME Council 75, on behalf of certified and registered family child care providers, regarding issues of mutual concern. Such issues of mutual concern may include, but are not limited to, training and certification requirements, reimbursement rates, payment procedures, health and safety conditions, and any other changes to current practice that would improve recruitment and retention of qualified[,] certified[,] and registered family child care providers, that would improve the quality of the programs they provide, or that would encourage exempt providers to seek to become certified or registered providers.

Id.; see also Steve Law, Day-Care, Statesman Journal (Salem, Or.), Sept. 1, 2005, at 1C (discussing the possibility of Oregon in-home day-care providers unionizing).

250. See Exec. Order No. 45, 29 Iowa Admin. Bull. 370 (2006) (directing the Department of Human Services to meet with authorized representatives of registered FCC providers in Iowa); Exec. Order No. 46, 29 Iowa Admin. Bull. 373 (2006) (directing the Department of Human Services to 
extending collective bargaining rights to FCC providers who serve families receiving publicly subsidized care. And in Washington, legislation has been introduced to extend collective bargaining rights to FCC providers. $^{251}$

\section{CONCLUSION}

Family child care is a critical component of child care in America. The popularity of family child care, especially for low-income communities and for poor women transitioning from welfare to work, has understandably heightened concern over the quality of such care, the lack of provider training, and the need for increased government regulation. Sustainable, long-term progress on these fronts requires a comprehensive approach that appreciates the link between improved child care quality and transformation of family child care into a decent job. As long as providers earn poverty-level wages and lack the resources to afford benefits such as health insurance, the problems of poor quality of care and high turnover rates among providers will persist.

While figuring out how to best resolve America's child care problem is a complicated task, this Article has argued that the labor movement can help assure that the solution reflects the interests and perspectives of FCC providers as well as the interests of children in child care. Whether unions challenge the classification of providers as independent contractors under existing labor laws or advocate for the creation of new laws that classify providers as employees for the purpose of collective bargaining, the ultimate goal is the same: to allow providers a voice in determining the terms and conditions under which they provide care, on behalf of the states, to children whose families receive child care subsidies.

meet with authorized representatives of unregistered FCC providers in Iowa); see also DeWitte, supra note 5 (stating that AFSCME claimed victory in a vote to decide which union would represent Iowa child care providers); Charlotte Eby, Union Says It Will Lead Efforts for Iowa's Child Care Providers, WATERLOO-CEDAR FALls COURIER (Iowa), Feb. 7, 2006, at A7 (stating that Iowa's child care workers had voted to join a union); Jacobs, supra note 5 (discussing the two executive orders).

251. See S.B. 6165, 59th Leg., Reg. Sess. (Wash. 2006) ("AN ACT Relating to improving access to and the stability of quality child care through providing collective bargaining and other representation rights for family child care providers and licensees."); H.B. 2353, 59th Leg., Reg. Sess. (Wash. 2006) (same). 